Prepared in cooperation with the Providence Water Supply Board

\title{
Streamflow, Water Quality, and Constituent Loads and Yields, Scituate Reservoir Drainage Area, Rhode Island, Water Year 2019
}

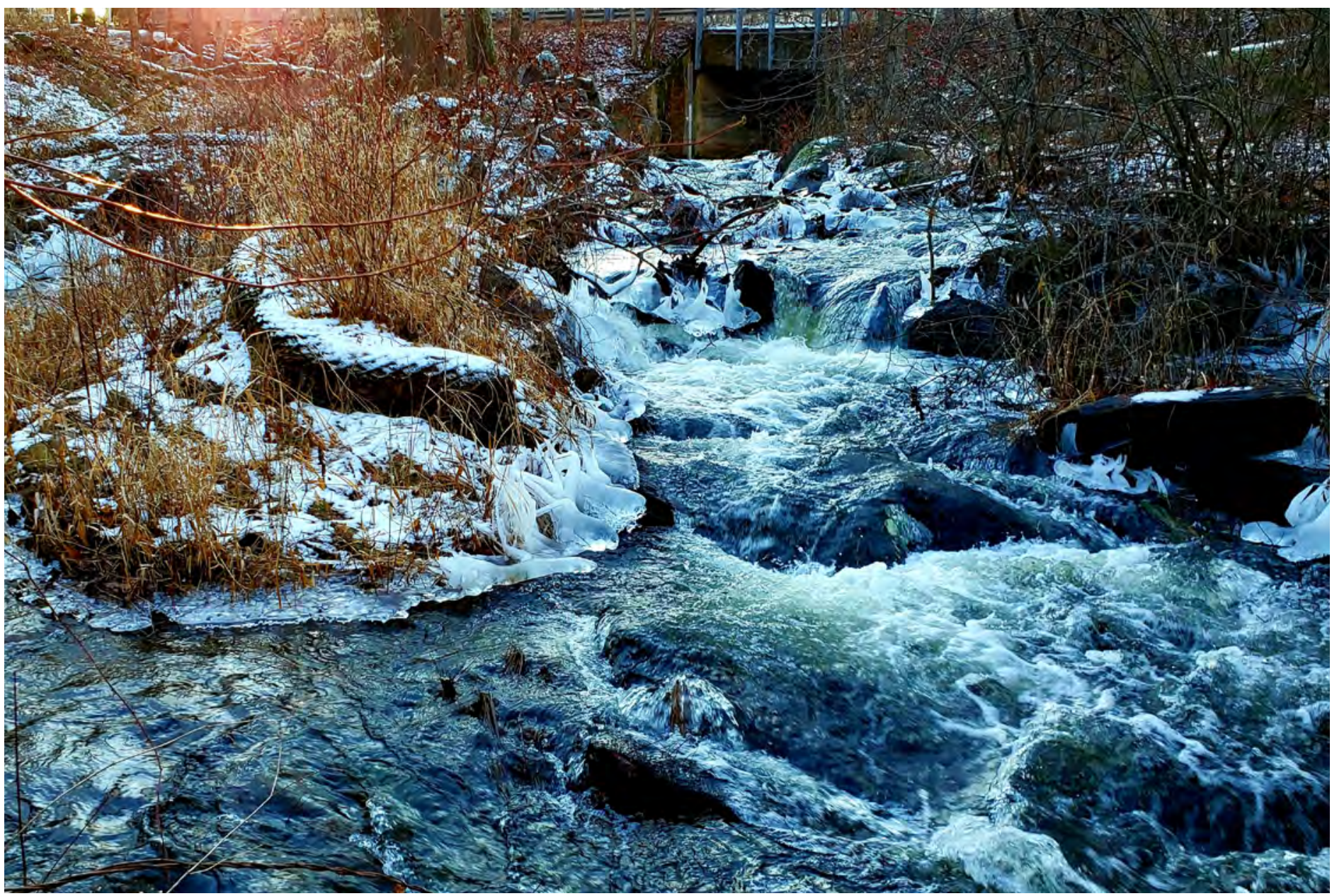

Data Report 1145

U.S. Department of the Interior

U.S. Geological Survey 
Cover. U.S. Geological Survey streamgage at Westconnaug Stream at Plainfield Pike, Rhode Island; photograph by the U.S. Geological Survey. 


\section{Streamflow, Water Quality, and Constituent Loads and Yields, Scituate Reservoir Drainage Area, Rhode Island, Water Year 2019}

By Kirk P. Smith

Prepared in cooperation with the Providence Water Supply Board

Data Report 1145 


\section{U.S. Geological Survey, Reston, Virginia: 2022}

For more information on the USGS - the Federal source for science about the Earth, its natural and living resources, natural hazards, and the environment—visit https://www.usgs.gov or call 1-888-ASK-USGS.

For an overview of USGS information products, including maps, imagery, and publications, visit https://store.usgs.gov/.

Any use of trade, firm, or product names is for descriptive purposes only and does not imply endorsement by the U.S. Government.

Although this information product, for the most part, is in the public domain, it also may contain copyrighted materials as noted in the text. Permission to reproduce copyrighted items must be secured from the copyright owner.

Suggested citation:

Smith, K.P., 2022, Streamflow, water quality, and constituent loads and yields, Scituate Reservoir drainage area, Rhode Island, water year 2019: U.S. Geological Survey Data Report 1145, 35 p., https://doi.org/10.3133/dr1145.

Associated data for this publication:

Smith, K.P., 2021, Water quality data from the Providence Water Supply Board for tributary streams to the Scituate Reservoir, water year 2018-19: U.S. Geological Survey data release, https://doi.org/10.5066/P9WK8NOF.

U.S. Geological Survey, 2020, USGS water data for the nation: U.S. Geological Survey National Water Information System database, https://doi.org/10.5066/F7P55KJN.

ISSN (online) [pending] 


\section{Contents}

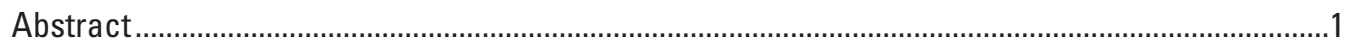

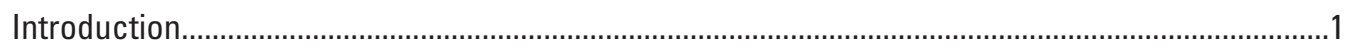

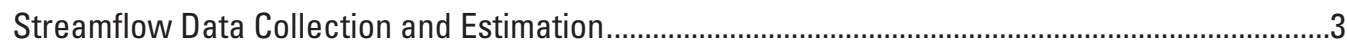

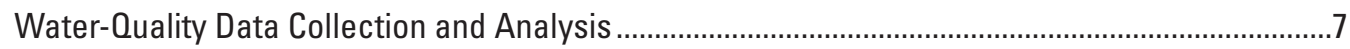

Data Collected by the U.S. Geological Survey .........................................................................

Data Collected by the Providence Water Supply Board ..........................................................

Estimating Daily, Monthly, and Annual Loads and Yields............................................................10

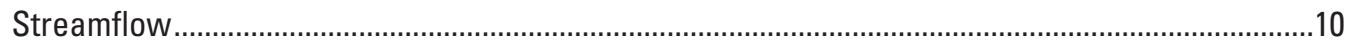

Water Quality and Constituent Loads and Yields .........................................................................11

Chloride and Sodium Loads and Yields Estimated from Specific-Conductance

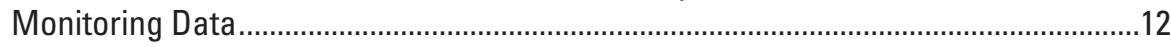

Physical and Chemical Properties and Daily Loads and Yields Estimated from Data

Collected by the Providence Water Supply Board .......................................................13

Physical and Chemical Properties ....................................................................................13

Constituent Concentrations and Daily Loads and Yields...............................................13

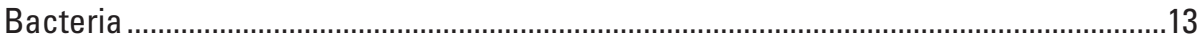

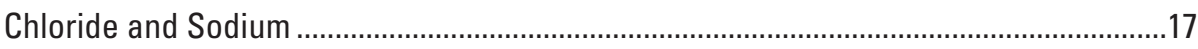

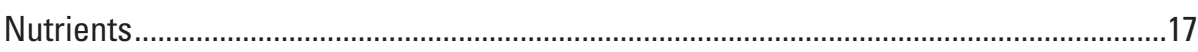

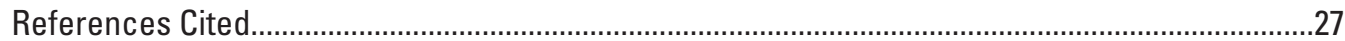

\section{Figures}

1. Map showing locations of tributary-reservoir subbasins and stations in the Scituate Reservoir drainage area, Rhode Island, in water year 2019...

2. Graph showing flow-duration curves and streamflow on the dates when water-quality samples were collected by the Providence Water Supply Board for the U.S. Geological Survey continuous streamgages on Rush Brook near Elmdale Road at north Scituate and Shippee Brook Tributary at north Foster, Rhode Island, for water year 2019.

3. Hydrologic data taken at the U.S. Geological Survey continuous-record streamgage on the Ponaganset river at south Foster, in the Scituate Reservoir drainage area, Rhode Island; graph showing measured daily mean streamflow for October 1, 2018, through September 30, 2019, and the 10th percentile, median, and 90th percentile values of daily streamflow for October 1, 1994, through September 30, 2018; and box plot showing annual mean streamflow during water year 2019 and the distribution of mean annual streamflows for water years 1994-2018.

4. Graph showing annual loads of chloride and sodium estimated from streamflow and specific conductance data for water year 2019 and associated minimum, maximum, and median annual loads for water years 2009-18 at 14 Providence Water Supply Board sampling stations in the Scituate Reservoir drainage area, Rhode Island...

5. Chart showing annual loads and annual yields of chloride and sodium estimated from continuous measurements of flow and specific conductance for water years 2009-19 for the area upstream from 14 Providence Water Supply Board sampling stations in the Scituate Reservoir drainage area, Rhode Island 


\section{Tables}

1. Providence Water Supply Board water-quality sampling stations, water-quality samples, and available streamflow and specific conductance monitoring in the Scituate Reservoir drainage area, Rhode Island, from October 1, 2018, to September 30, 2019.

2. Measured or estimated annual mean streamflow for tributary streams in the Scituate Reservoir drainage area, Rhode Island, from October 1, 2018, through September 30, 2019... .6

3. Regression equation coefficients used to estimate concentrations of chloride and sodium from values of specific conductance for U.S. Geological Survey streamgage stations in the Scituate Reservoir drainage area, Rhode Island, from October 1, 2018, through September 30, 2019.

4. Daily loads of bacteria, chloride, nitrite, nitrate, and orthophosphate in the Scituate Reservoir drainage area, Rhode Island, from October 1, 2018, through September 30, 2019...

5. Monthly mean concentrations of chloride and sodium estimated from continuous measurements of specific conductance in the Scituate Reservoir drainage area, Rhode Island, October 1, 2018, through September 30, 2019

6. Annual mean chloride and sodium concentrations, loads, and yields for sampling stations in the Scituate Reservoir drainage area, Rhode Island, from October 1, 2018, through September 30, 2019

7. Monthly estimated chloride and sodium loads by sampling station, in the Scituate Reservoir drainage area, Rhode Island, October 1, 2018, through September 30, 2019.

8. Median values for water-quality data collected at Providence Water Supply Board stations in the Scituate Reservoir drainage area, Rhode Island, from October 1, 2018, through September 30, 2019

9. Median daily loads of bacteria, chloride, nitrite, nitrate, and orthophosphate in the Scituate Reservoir drainage area, Rhode Island, from October 1, 2018, through September 30, 2019

10. Median daily yields of bacteria, chloride, nitrite, nitrate, and orthophosphate in the Scituate Reservoir drainage area, Rhode Island, from October 1, 2018, through September 30, 2019 


\section{Conversion Factors}

U.S. customary units to International System of Units

\begin{tabular}{lll}
\hline \multicolumn{1}{c}{ Multiply } & By & \multicolumn{1}{c}{ To obtain } \\
\hline mile $(\mathrm{mi})$ & 1.609 & kilometer $(\mathrm{km})$ \\
square mile $\left(\mathrm{mi}^{2}\right)$ & 2.590 & square kilometer $\left(\mathrm{km}^{2}\right)$ \\
cubic foot per second $\left(\mathrm{ft}^{3} / \mathrm{s}\right)$ & 0.02832 & cubic meter per second $\left(\mathrm{m}^{3} / \mathrm{s}\right)$ \\
ton, short $(2,000 \mathrm{lb})$ & 0.9072 & metric ton $(\mathrm{t})$ \\
\hline
\end{tabular}

\section{Datum}

Vertical coordinate information is referenced to north American Vertical Datum of 1988 (NAVD 88).

Horizontal coordinate information is referenced to north American Datum of 1983 (NAD 83).

Altitude, as used in this report, refers to distance above the vertical datum.

\section{Supplemental Information}

Concentrations of constituents in water are given in either milligrams per liter ( $\mathrm{mg} / \mathrm{L}$ ) or colony forming units per 100 milliliters (CFU/100 mL).

Loads of constituents in water are given in kilograms $(\mathrm{kg})$, and daily loads are given in grams per day $(\mathrm{g} / \mathrm{d})$, kilograms per day $(\mathrm{kg} / \mathrm{d})$, kilograms per year $(\mathrm{kg} / \mathrm{yr})$, metric tons per year $(\mathrm{t} / \mathrm{yr})$, or million colony forming units per day (CFU $\left.\times 10^{6} / \mathrm{d}\right)$.

Yields are given in grams per day per square $\mathrm{mile}\left(\mathrm{g} / \mathrm{d} / \mathrm{mi}^{2}\right)$, kilograms per day per square mile $\left(\mathrm{kg} / \mathrm{d} / \mathrm{mi}^{2}\right)$, kilograms per year per square mile $\left(\mathrm{kg} / \mathrm{yr} / \mathrm{mi}^{2}\right)$, metric tons per year per square mile $\left(\mathrm{t} / \mathrm{yr} / \mathrm{mi}^{2}\right)$, or million colony forming units per day per square mile (CFU $\left.\times 10^{6} / \mathrm{d} / \mathrm{mi}^{2}\right)$.

\section{Abbreviations}

E. coli Escherichia coli

MOVE.1 Maintenance of Variance Extension type 1

NWIS National Water Information System

PWSB Providence Water Supply Board

USGS U.S. Geological Survey

WY water year 



\title{
Streamflow, Water Quality, and Constituent Loads and Yields, Scituate Reservoir Drainage Area, Rhode Island, Water Year 2019
}

\author{
By Kirk P. Smith
}

\section{Abstract}

As part of a long-term cooperative program to monitor water quality within the Scituate Reservoir drainage area, the U.S. Geological Survey in cooperation with the Providence Water Supply Board collected streamflow and water-quality data at the Scituate Reservoir and tributaries. Streamflow and concentrations of chloride and sodium estimated from records of specific conductance were used to calculate loads of chloride and sodium during water year 2019 (October 1, 2018, through September 30, 2019) for tributaries to the Scituate Reservoir, Rhode Island. Streamflow was measured or estimated by the U.S. Geological Survey following standard methods at 23 streamgages; 14 of these streamgages are equipped with instrumentation capable of continuously monitoring water level, specific conductance, and water temperature. Water-quality samples were collected by the Providence Water Supply Board at 37 sampling stations, which also include the 14 continuous-record streamgages maintained by the U.S. Geological Survey, during water year 2019 as part of a long-term sampling program; all stations are in the Scituate Reservoir drainage area. Water-quality data collected by the Providence Water Supply Board are summarized by using values of central tendency and are used, in combination with measured (or estimated) streamflows, to calculate loads and yields (loads per unit area) of selected water-quality constituents for water year 2019.

The largest tributary to the reservoir, the Ponaganset River, which was monitored by the U.S. Geological Survey, contributed a mean streamflow of 40 cubic feet per second to the reservoir during water year 2019. For the same period, annual mean streamflows measured (or estimated) for the other monitoring stations in this study ranged from about 0.55 to about 26 cubic feet per second. Together, tributaries equipped with instrumentation capable of continuously monitoring specific conductance transported about 3,500 metric tons of chloride and 2,100 metric tons of sodium to the Scituate Reservoir during water year 2019; annual chloride yields for the tributaries ranged from 20 to 180 metric tons per square mile, and annual sodium yields ranged from 14 to 100 metric tons per square mile.
At the stations where water-quality samples were collected by the Providence Water Supply Board, the medians of the median concentrations were 25.1 milligrams per liter for chloride, 0.001 milligram per liter as nitrogen for nitrite, 0.08 milligram per liter as nitrogen for nitrate, 0.03 milligram per liter as phosphate for orthophosphate, 1,000 colony forming units per 100 milliliters for total coliform bacteria, and 10 colony forming units per 100 milliliters for Escherichia coli (E. coli). The medians of the median daily loads of chloride, nitrite, nitrate, orthophosphate, total coliform, and E. coli bacteria were 340 kilograms per day, 18 grams per day, 1,000 grams per day, 410 grams per day, 81,000 million colony forming units per day, and less than 1,800 million colony forming units per day, respectively. The medians of the median yields of chloride, nitrite, nitrate, orthophosphate, total coliform, and E. coli bacteria were 140 kilograms per day per square mile, 6.8 grams per day per square mile, 440 grams per day per square mile, 140 grams per day per square mile, 32,000 million colony forming units per day per square mile, and 660 million colony forming units per day per square mile, respectively.

\section{Introduction}

The Scituate Reservoir is the primary source of drinking water for more than 60 percent of the population of Rhode Island. The Scituate Reservoir drainage area consists of six subbasins and covers an area of about 94 square miles in parts of the towns of Cranston, Foster, Glocester, Johnston, and Scituate, Rhode Island (fig. 1). Information about the water quality of the reservoir and its tributaries is important for management of the water supply and for the protection of human health. The Providence Water Supply Board (PWSB), which is the agency responsible for the management and distribution of the Scituate Reservoir water supply, has been monitoring and assessing water quality in the reservoir and reservoir drainage area for more than 60 years.

Since 1993, the U.S. Geological Survey (USGS) has been cooperating with the PWSB and the Rhode Island Department of Environmental Management to measure streamflow in 


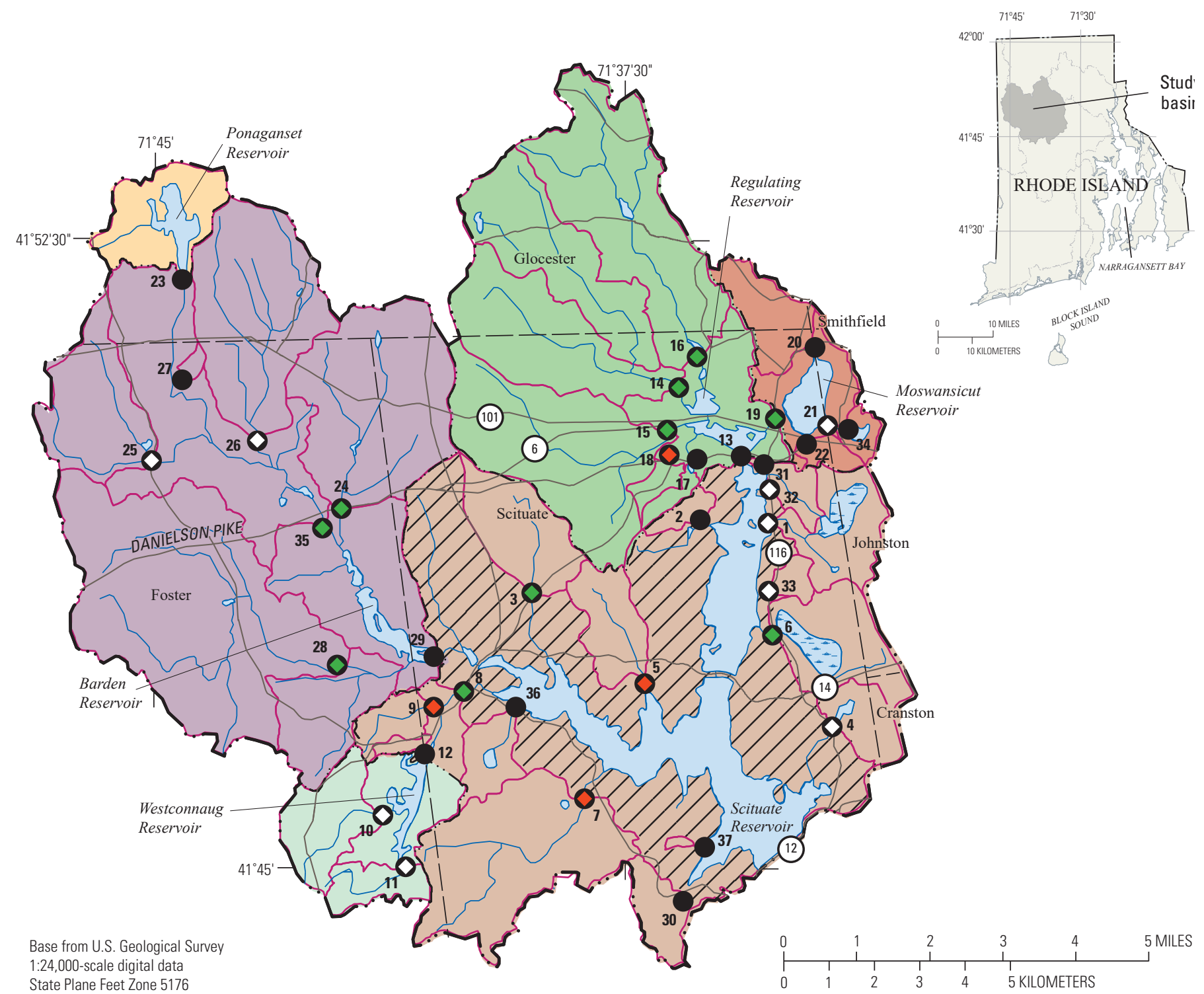

EXPLANATION
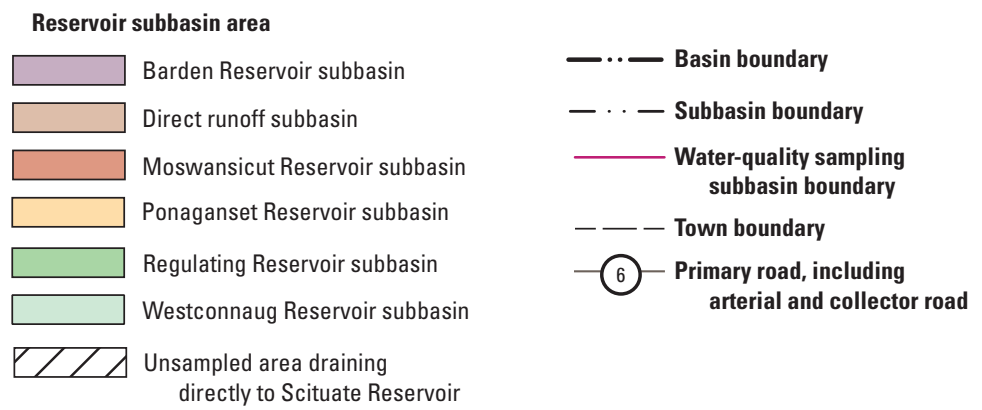
Streamflow or water-quality monitoring station and identifier
Providence Water Supply Board
22 water-quality sampling station and number
Providence Water Supply Board water-quality
35 sampling station and U.S. Geological Survey continuous streamgage and water-quality monitoring station
Providence Water Supply Board water-quality
7 sampling station and U.S. Geological Survey continuous water-quality monitoring station
$\checkmark$ Providence Water Supply Board water-quality sampling station and U.S. Geological Survey partial-record station

Figure 1. Locations of tributary-reservoir subbasins and stations in the Scituate Reservoir drainage area, Rhode Island, in water year 2019. 
tributaries to the Scituate Reservoir. Streamflow has been continuously measured at 10 streamgages in the drainage area (table 1) since 2009 by the USGS. Streamflow also was continuously measured at four streamgages from 2009 to 2014 and periodically measured at nine additional streamgages on tributaries in the drainage area. At the 13 streamgages without continuous flow data, daily mean streamflow has been estimated by using methods developed by the USGS (table 1; Hirsch, 1982). The USGS also has been continuously measuring specific conductance at 14 monitoring stations since 2009 (table 1). Equations that relate specific conductance to concentrations of chloride and sodium in stream water were developed as part of previous cooperative studies of the USGS and the PWSB (Nimiroski and Waldron, 2002; Smith, 2015b, 2018a, 2021a). These equations, used together with measured (or estimated) streamflows, allow for nearly continuous estimation of chloride and sodium loads to the reservoir.

In 2019, the PWSB regularly, either monthly or quarterly, visited fixed sites on 37 tributaries within the Scituate Reservoir drainage area and collected water-quality samples. Compiled and tabulated streamflow (measured or estimated by the USGS) and water-quality data (collected by the PWSB) have been published in Breault and others (2000), Nimiroski and others (2008), Breault (2010), Breault and Campbell (2010a-d), Breault and Smith (2010), Smith and Breault (2011), and Smith (2013, 2014, 2015a, b, 2016, 2018a-d, 2019a, b, 2021a, b).

This report presents data on streamflow, water quality, and loads and yields of selected constituents for water year $(\mathrm{WY})^{1} 2019$ in the Scituate Reservoir drainage area. These data were collected as part of studies done by the USGS in cooperation with the PWSB and the Rhode Island Department of Environmental Management. A summary of measured and estimated streamflows is presented for the 10 continuousrecord and 13 partial-record streamgages in the drainage area. Estimated monthly and annual loads and yields of chloride and sodium are presented for the 14 streamgages at which specific conductance is continuously monitored by the USGS. Summary statistics for water-quality data collected by the PWSB for 37 sampling stations (table 1) during WY 2019 also are presented, and these data were used to calculate loads and yields of selected water-quality constituents where flow data were available.

\footnotetext{
${ }^{1} \mathrm{~A}$ water year is the period between October 1 and September 30 and is designated by the year in which it ends.
}

\section{Streamflow Data Collection and Estimation}

Streamflow was measured or estimated by the USGS at 23 streamgages (table 1). Measured and estimated streamflows are necessary to estimate water volume and water-quality constituent loads and yields from tributary basins. Stream stage was measured every 10 minutes at most continuous-record streamgages. Streamflow was computed with a stage-discharge relation (known as a rating), which was developed on the basis of periodic manual measurements of streamflow. Daily mean streamflow at a streamgage was calculated by dividing the total volume of water that passed the streamgage each day by 86,400 (the number of seconds in a day). Periodic manual streamflow measurements at partial-record streamgages were used concurrently with continuous-record measurements from streamgages in nearby hydrologically similar drainage areas to estimate a continuous daily record at the partial-record streamgages. Specifically, daily streamflow records for the 13 partial-record sites in the Scituate Reservoir drainage area (table 1) were estimated by using the Maintenance of Variance Extension type 1 (MOVE.1) method, as described by Ries and Friesz (2000) and Smith (2015b); data needed to estimate streamflows at partial-record sites were retrieved from the USGS National Water Information System (NWIS; U.S. Geological Survey, 2020). The upper and lower 90-percent confidence limits for the estimated mean annual streamflows, as described by Tasker and Driver (1988), are listed in table 2 . These data indicate that there is a 90 -percent chance that the estimated mean annual streamflow is between the upper and lower 90-percent confidence limits.

Continuous-record streamgages were operated and maintained by the USGS during WY 2019 in cooperation with the PWSB (fig. 1; table 1). Streamflow data for these streamgages were collected at 10- or 15-minute intervals (near-real-time streamflow data), were updated at 1-hour intervals on the internet, and are available through the NWIS web interface (U.S. Geological Survey, 2020). Error associated with measured streamflows was generally within about 15 percent as noted in the annual water year summary for each USGS streamgage. 
Table 1. Providence Water Supply Board water-quality sampling stations, water-quality samples, and available streamflow and specific conductance monitoring in the Scituate Reservoir drainage area, Rhode Island, from October 1, 2018, to September 30, 2019.

[Alternate station names given in parenthesis for stations where different historical names were used for the same sampling location by the Providence Water Supply Board (PWSB). Locations of stations are shown in figure 1. USGS, U.S. Geological Survey; $\mathrm{mi}^{2}$, square mile; QW, water quality; M, monthly; Q, quarterly; Y, yes; $\mathrm{N}$, no; Na, sodium; $\mathrm{Cl}$, chloride; - , none]

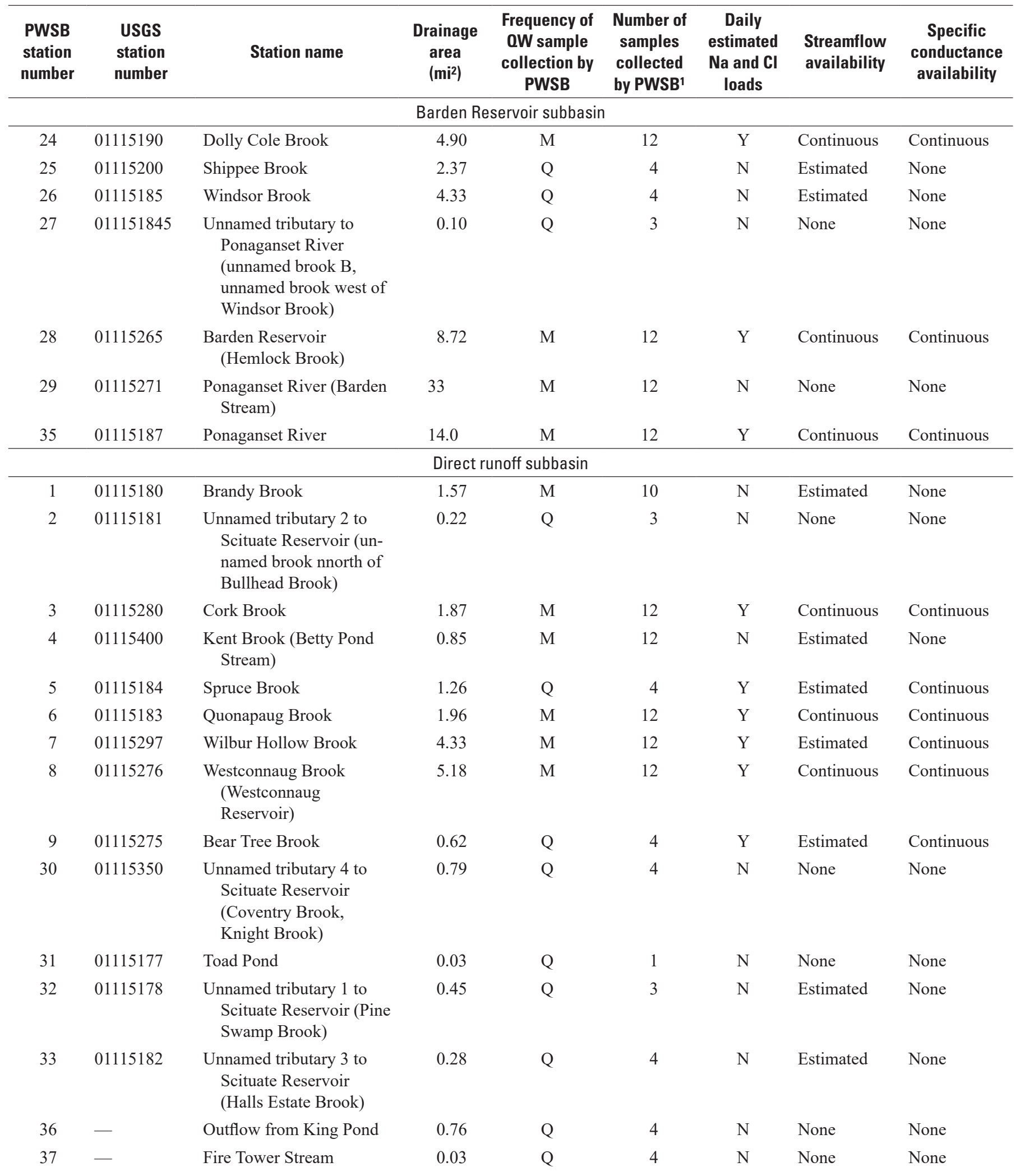


Table 1. Providence Water Supply Board water-quality sampling stations, water-quality samples, and available streamflow and specific conductance monitoring in the Scituate Reservoir drainage area, Rhode Island, from October 1, 2018, to September 30, 2019.Continued

[Alternate station names given in parenthesis for stations where different historical names were used for the same sampling location by the Providence Water Supply Board (PWSB). Locations of stations are shown in figure 1. USGS, U.S. Geological Survey; mi² $^{2}$ square mile; QW, water quality; M, monthly; Q, quarterly; Y, yes; N, no; Na, sodium; $\mathrm{Cl}$, chloride; —, none]

\begin{tabular}{|c|c|c|c|c|c|c|c|c|}
\hline $\begin{array}{l}\text { PWSB } \\
\text { station } \\
\text { number }\end{array}$ & $\begin{array}{l}\text { USGS } \\
\text { station } \\
\text { number }\end{array}$ & Station name & $\begin{array}{l}\text { Drainage } \\
\text { area } \\
\left(\mathrm{mi}^{2}\right)\end{array}$ & $\begin{array}{l}\text { Frequency of } \\
\text { OW sample } \\
\text { collection by } \\
\text { PWSB }\end{array}$ & $\begin{array}{l}\text { Number of } \\
\text { samples } \\
\text { collected } \\
\text { by PWSB } 1\end{array}$ & $\begin{array}{l}\text { Daily } \\
\text { estimated } \\
\text { Na and Cl } \\
\text { loads }\end{array}$ & $\begin{array}{l}\text { Streamflow } \\
\text { availability }\end{array}$ & $\begin{array}{c}\text { Specific } \\
\text { conductance } \\
\text { availability }\end{array}$ \\
\hline \multicolumn{9}{|c|}{ Moswansicut Reservoir subbasin } \\
\hline 19 & 01115170 & $\begin{array}{l}\text { Moswansicut Reservoir } \\
\text { (Moswansicut Stream } \\
\text { north, Moswansicut } \\
\text { Pond) }\end{array}$ & 3.25 & M & 12 & $\mathrm{Y}$ & Continuous & Continuous \\
\hline 20 & 01115160 & $\begin{array}{l}\text { Unnamed tributary } 1 \text { to } \\
\text { Moswansicut Reservoir } \\
\text { (Blanchard Brook) }\end{array}$ & 1.18 & M & 11 & $\mathrm{~N}$ & None & None \\
\hline 21 & 01115165 & $\begin{array}{l}\text { Unnamed tributary } 2 \text { to } \\
\text { Moswansicut Reservoir } \\
\text { (Brook from Kimball } \\
\text { Reservoir) }\end{array}$ & 0.30 & Q & 2 & $\mathrm{~N}$ & Estimated & None \\
\hline 34 & 01115164 & Kimball Stream & 0.27 & Q & 4 & $\mathrm{~N}$ & None & None \\
\hline \multicolumn{9}{|c|}{ Ponaganset Reservoir subbasin } \\
\hline 23 & 011151843 & Ponaganset Reservoir & 1.92 & $\mathrm{M}$ & 11 & $\mathrm{~N}$ & None & None \\
\hline \multicolumn{9}{|c|}{ Regulating Reservoir subbasin } \\
\hline 13 & 01115176 & Regulating Reservoir & 22.1 & $\mathrm{M}$ & 11 & $\mathrm{~N}$ & None & None \\
\hline 14 & 01115110 & Huntinghouse Brook & 6.29 & M & 12 & Y & Continuous & Continuous \\
\hline 15 & 01115114 & Rush Brook & 4.70 & M & 12 & $\mathrm{Y}$ & Continuous & Continuous \\
\hline 10 & 01115274 & Westconnaug Brook & 1.48 & M & 12 & $\mathrm{~N}$ & Estimated & None \\
\hline 11 & 01115273 & $\begin{array}{l}\text { Unnamed tributary to } \\
\text { Westconnaug Reservoir } \\
\text { (unnamed brook } \\
\text { ssouth of Westconnaug } \\
\text { Reservoir) }\end{array}$ & 0.72 & Q & 4 & $\mathrm{~N}$ & Estimated & None \\
\hline 12 & 011152745 & $\begin{array}{l}\text { Unnamed tributary to } \\
\text { Westconnaug Brook } \\
\text { (unnamed brook nnorth } \\
\text { of Westconnaug reser- } \\
\text { voir) }\end{array}$ & 0.16 & Q & 3 & $\mathrm{~N}$ & None & None \\
\hline
\end{tabular}

${ }^{1}$ Not all samples were analyzed for all water-quality properties or constituents. 
Table 2. Measured or estimated annual mean streamflow for tributary streams in the Scituate Reservoir drainage area, Rhode Island, from October 1, 2018, through September 30, 2019.

[Alternate station names are listed in parentheses for stations where different historical names were used for the same sampling location by the Providence Water Supply Board (PWSB). Locations of stations are shown on figure 1. USGS, U.S. Geological Survey; $\mathrm{ft}^{3} / \mathrm{s}$, cubic foot per second; $\mathrm{ft}^{3} / \mathrm{s} / \mathrm{mi}^{2}$, $\mathrm{cubic}$ foot per second per square mile]

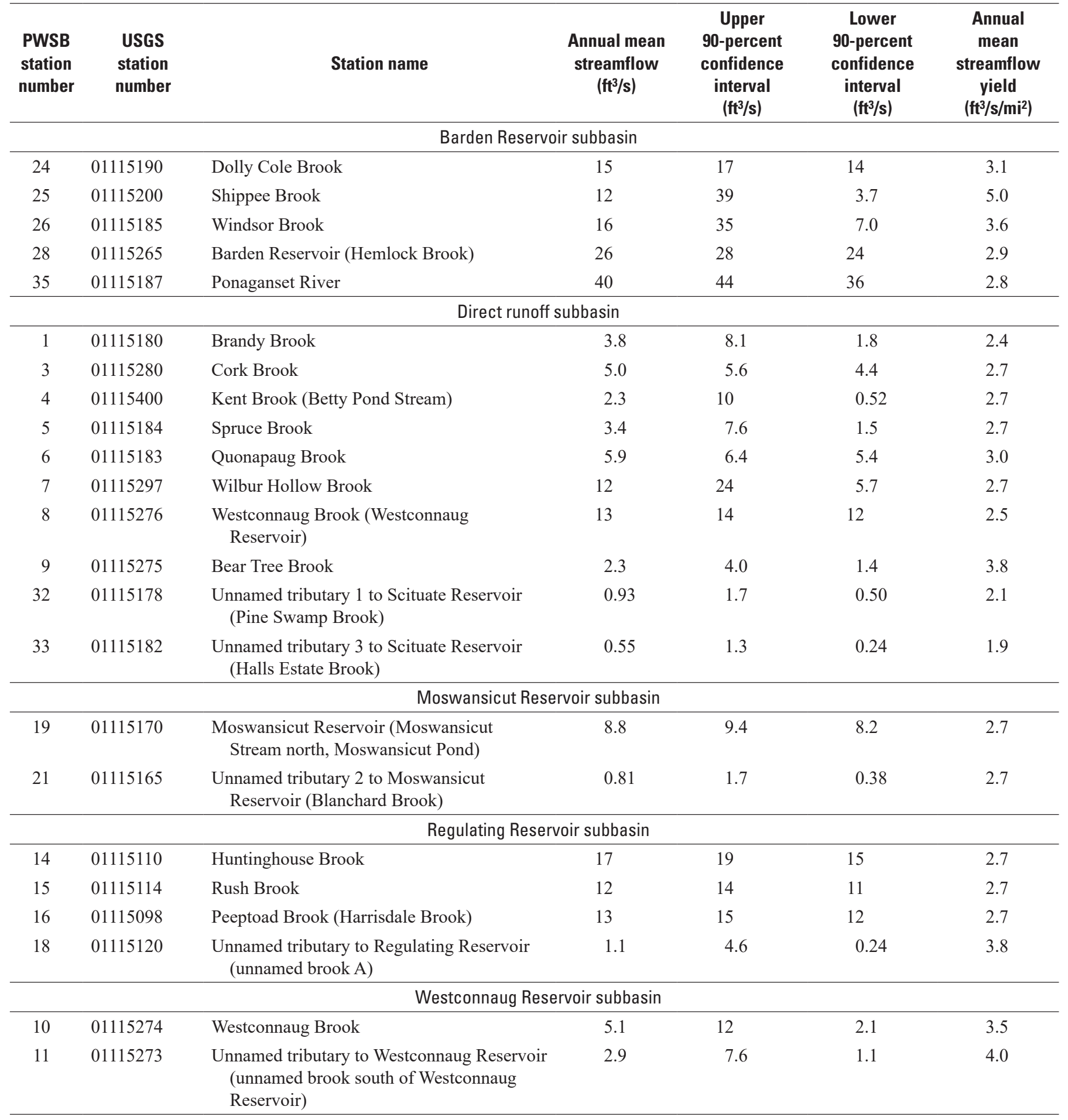




\section{Water-Quality Data Collection and Analysis}

Water-quality data were collected by the USGS and the PWSB. Concentrations of sodium and chloride were estimated by the USGS from continuous records of specific conductance from 14 of the 23 streamgages. Water-quality samples were collected monthly or quarterly at 37 sampling stations in the Scituate Reservoir drainage area by the PWSB during WY 2019 as part of a long-term sampling program (table 1).

\section{Data Collected by the U.S. Geological Survey}

Three or more water-quality samples were collected by the USGS from 14 tributaries equipped with continuous specific conductance monitors in the Scituate Reservoir drainage area during water year 2019 (table 1). Samples were collected in the centroid of the streams during the fall, winter, and summer months. Water samples were processed in the USGS New England Water Science Center laboratory in Northborough, Massachusetts, at the conclusion of scheduled sampling. After the processing, the samples were packed in ice and shipped overnight to the USGS National Water Quality Laboratory in Lakewood, Colorado. Analytical results for the USGS waterquality samples are available through the NWIS web interface (U.S. Geological Survey, 2020).

The USGS collected and analyzed continuous-record specific conductance data at 14 streamgages (fig. 1; table 1). Measurements of specific conductance were recorded automatically at 10- or 15-minute intervals at each streamgage. Measurements were made by using an instream probe and standard USGS methods for continuous water-quality monitoring at streams (Wagner and others, 2006). The specific conductance measurement data are available through the NWIS web interface (U.S. Geological Survey, 2020).

Concentrations of chloride and sodium were estimated from continuous measurements of specific conductance by using equations that were developed by the USGS to relate specific conductance to concentrations of chloride and sodium, as follows:

$$
\begin{gathered}
C_{C l}=S P C^{m \times b} \text { and } \\
C_{N a}=S P C^{m \times b},
\end{gathered}
$$

where

$$
\begin{aligned}
& C_{C l} \text { is the chloride concentration, in milligrams } \\
& \text { per liter; } \\
& C_{N a} \text { is the sodium concentration, in milligrams } \\
& \text { per liter; } \\
& S P C \quad \text { is the specific conductance, in microsiemens } \\
& \text { per centimeter; } \\
& m \quad \text { is the slope from the MOVE. } 1 \text { analysis } \\
& \text { (table 3); and } \\
& b \quad \text { is the intercept from the MOVE. } 1 \text { analysis } \\
& \text { (table 3). }
\end{aligned}
$$

These regression equations were developed by using the MOVE. 1 method (also known as the line of organic correlation; Helsel and Hirsch, 2002) on the basis of concurrent measurements of specific conductance (USGS parameter code 90095) along with chloride (USGS parameter code 00940) and sodium (USGS parameter code 00930) concentrations measured in water-quality samples collected by the USGS from tributaries in the Scituate Reservoir drainage area during WY 2000, WY 2005, and WY 2009-20 (table 3; U.S. Geological Survey, 2020).

MOVE. 1 was chosen for regression analysis to maintain variance (Hirsch and Gilroy, 1984). Under some circumstances, specific conductance records were unavailable because a sensor malfunctioned, was affected by debris, fouling, or ice, or was not submerged during low flow. In these cases, values of specific conductance were estimated by proportional distribution between recorded values. In general, the period of specific conductance record that was unavailable for each USGS station represents a small fraction of the record period for WY 2019 (table 3).

\section{Data Collected by the Providence Water Supply Board}

Water-quality samples were collected by the PWSB at 37 fixed stations on tributaries draining to the Scituate Reservoir during WY 2019. Sampling visits typically are conducted monthly at 19 stations and quarterly at another 18 stations (table 1).

Water-quality samples were not collected during specific weather conditions; instead, a periodic water-quality sampling schedule was followed so that water-quality samples would be representative of various weather conditions. However, sometimes samples could not be collected because tributaries at the sampling stations were dry or frozen. When possible, water-quality samples were collected by dipping the sample bottle into the tributary at the center of flow (Richard Blodgett, PWSB, written commun., 2005). Samples were transported on ice to the PWSB water-quality laboratory at the P.J. Holton Water Purification Plant in Scituate. Water-quality properties and constituent concentrations were measured by using unfiltered water samples. These water-quality properties included $\mathrm{pH}$, alkalinity, color, turbidity, and concentrations of chloride, nitrite, nitrate, orthophosphate, and bacteria (Escherichia coli [E. coli] and total coliform); these data collected by the PWSB are published in Smith (2021b). Analytical methods used for the determination of values or concentrations of $\mathrm{pH}$, color, turbidity, alkalinity, and chloride are documented by Baird and others (2018). Concentrations of nitrite were determined by U.S. Environmental Protection Agency method 353.2 (U.S. Environmental Protection Agency, 1993). Concentrations of nitrate were determined by Standard Method $4500-\mathrm{NO}_{3}$ (Holm and others, 2018). Concentrations of orthophosphate were determined by the Hach PhosVer Method (Hach Method 
Table 3. Regression equation coefficients used to estimate concentrations of chloride and sodium from values of specific conductance for U.S. Geological Survey streamgage stations in the Scituate Reservoir drainage area, Rhode Island, from October 1, 2018, through September 30, 2019.

[Constituent concentrations and continuous specific conductance available in National Water Information System (U.S. Geological Survey, 2020). Locations of stations are shown in figure 1. U.S. Geological Survey (USGS) parameter codes: specific conductance, 90095; chloride, 00940; sodium, 00930. PWSB, Providence Water Supply Board; <, less than]

\begin{tabular}{|c|c|c|c|c|c|c|c|c|c|c|}
\hline \multirow[b]{2}{*}{$\begin{array}{l}\text { PWSB } \\
\text { station } \\
\text { number }\end{array}$} & \multirow[b]{2}{*}{$\begin{array}{l}\text { USGS } \\
\text { station } \\
\text { number }\end{array}$} & \multicolumn{2}{|c|}{ Samples used in analyses } & \multicolumn{3}{|c|}{ Chloride } & \multicolumn{3}{|c|}{ Sodium } & \multirow{2}{*}{$\begin{array}{c}\text { Amount of specific } \\
\text { conductance re- } \\
\text { cord unavailable } \\
\text { where discharge } \\
\text { is greater than zero } \\
\text { (percent) }\end{array}$} \\
\hline & & $\begin{array}{c}\text { Sample date range (month/day/ } \\
\text { year) }\end{array}$ & $\begin{array}{l}\text { Sample } \\
\text { count }\end{array}$ & Slope & Intercept & $\begin{array}{l}\text { Standard } \\
\text { error of } \\
\text { regressions } \\
\text { (percent) }\end{array}$ & Slope & Intercept & $\begin{array}{l}\text { Standard } \\
\text { error of } \\
\text { regressions } \\
\text { (percent) }\end{array}$ & \\
\hline 24 & 01115190 & $\begin{array}{l}03 / 08 / 2000 ; 03 / 29 / 2005 \\
01 / 22 / 2009 \text { to } 01 / 29 / 2020\end{array}$ & 33 & 1.2568 & 0.06927 & 2.3 & 1.2341 & 0.04747 & 4.6 & $<0.1$ \\
\hline 28 & 01115265 & $\begin{array}{l}03 / 28 / 2001 ; 03 / 30 / 2005 \\
01 / 22 / 2009 \text { to } 01 / 29 / 2020\end{array}$ & 34 & 1.2272 & 0.07969 & 3.4 & 1.1145 & 0.08224 & 5.7 & 0.5 \\
\hline 35 & 01115187 & $\begin{array}{l}03 / 28 / 2001 ; 03 / 29 / 2005 \\
01 / 22 / 2009 \text { to } 01 / 14 / 2020\end{array}$ & 33 & 1.0644 & 0.16539 & 4.3 & 1.1690 & 0.06355 & 5.4 & $<0.1$ \\
\hline 3 & 01115280 & $\begin{array}{l}03 / 08 / 2000 ; 03 / 30 / 2005 ; \\
01 / 22 / 2009 \text { to } 01 / 14 / 2020\end{array}$ & 33 & 1.2248 & 0.07611 & 3.0 & 1.1018 & 0.08370 & 5.0 & $<0.1$ \\
\hline 5 & 01115184 & $03 / 05 / 2009$ to $01 / 29 / 2020$ & 30 & 1.2604 & 0.06112 & 4.0 & 1.0811 & 0.08487 & 4.4 & $<0.1$ \\
\hline 6 & 01115183 & $\begin{array}{l}03 / 08 / 2000 ; 03 / 30 / 2005 \\
01 / 22 / 2009 \text { to } 01 / 28 / 2020\end{array}$ & 43 & 1.1794 & 0.08455 & 4.2 & 1.2057 & 0.04413 & 5.9 & $<0.1$ \\
\hline 7 & 01115297 & $\begin{array}{l}03 / 28 / 2001 ; 03 / 30 / 2005 \\
01 / 22 / 2009 \text { to } 01 / 14 / 2020\end{array}$ & 33 & 1.0728 & 0.12410 & 4.1 & 0.88661 & 0.17736 & 5.8 & $<0.1$ \\
\hline 8 & 01115276 & $01 / 22 / 2009$ to $01 / 29 / 2020$ & 30 & 1.0995 & 0.13738 & 2.9 & 1.0392 & 0.11477 & 3.8 & $<0.1$ \\
\hline 9 & 01115275 & $\begin{array}{l}03 / 08 / 2000 ; 03 / 30 / 2005 ; \\
01 / 22 / 2009 \text { to } 01 / 29 / 2020\end{array}$ & 32 & 1.0585 & 0.17773 & 2.5 & 1.0720 & 0.09770 & 3.4 & $<0.1$ \\
\hline 19 & 01115170 & $\begin{array}{l}03 / 08 / 2000 ; 03 / 29 / 2005 \\
01 / 22 / 2009 \text { to } 01 / 14 / 2020\end{array}$ & 39 & 1.2116 & 0.07599 & 2.6 & 1.2080 & 0.04599 & 2.8 & 2.2 \\
\hline 14 & 01115110 & $\begin{array}{l}03 / 28 / 2001 ; 03 / 29 / 2005 \\
01 / 22 / 2009 \text { to } 01 / 14 / 2020\end{array}$ & 41 & 1.1225 & 0.10393 & 7.1 & 1.0317 & 0.09412 & 7.7 & 2.1 \\
\hline 15 & 01115114 & $01 / 22 / 2009$ to $01 / 28 / 2020$ & 47 & 1.1441 & 0.11191 & 2.9 & 1.0839 & 0.09260 & 5.2 & 3.1 \\
\hline 16 & 01115098 & $\begin{array}{l}03 / 28 / 2001 ; 03 / 29 / 2005 \\
01 / 22 / 2009 \text { to } 01 / 14 / 2020\end{array}$ & 34 & 1.2598 & 0.05894 & 4.3 & 1.0895 & 0.08335 & 6.3 & $<0.1$ \\
\hline 18 & 01115120 & $01 / 22 / 2009$ to $01 / 14 / 2020$ & 26 & 1.1633 & 0.09758 & 2.8 & 1.1463 & 0.06160 & 3.4 & $<0.1$ \\
\hline
\end{tabular}


8048; Hach Company, 2000). Standard Method 9223 was used for the determination of concentrations of bacteria (Best and others, 2018).

Water-quality samples were collected by the PWSB during a wide range of flow conditions. The daily mean flow-duration curves for the Rush Brook near Elmdale Road at north Scituate (01115114; PWSB station 15) and Shippee Brook Tributary at north Foster, Rhode Island (01115200; PWSB station 25), USGS streamgages for WY 2019 are shown in figure 2 . The curves represent the percentage of time that each flow duration was equaled or exceeded at the respective stations; the flows at each station on days when waterquality samples were collected are represented by the plotted points superimposed on the curves. At Rush Brook, samples were collected at flow durations ranging from the 18.8th percentile to the 92.7 th percentile; this range indicates that with exception of high-end flows, the water-quality samples collected in WY 2019 generally represented most of the flow conditions during that water year. Samples collected only on a quarterly schedule at Shippee Brook encompassed about half of the range of flow conditions (from the 13.3th percentile to the 66.1th percentile) at this station during WY 2019 (fig. 2), excluding the highest flow conditions and much of lowflow range.

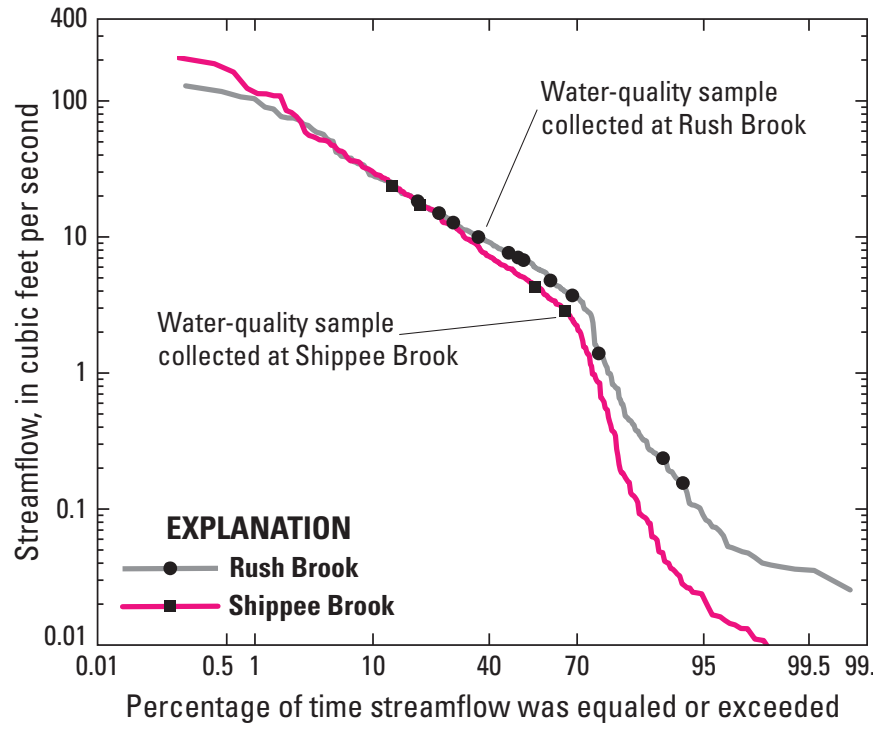

Figure 2. Flow-duration curves and streamflow on the dates (represented by points) when water-quality samples were collected by the Providence Water Supply Board for the U.S. Geological Survey continuous streamgages on Rush Brook near Elmdale Road at north Scituate (01115114) and Shippee Brook Tributary at north Foster, Rhode Island (01115200), for water year 2019. Locations of stations are shown on figure 1. 


\section{Estimating Daily, Monthly, and Annual Loads and Yields}

Daily, monthly, and annual chloride and sodium loads (in kilograms) were estimated for all streamgages for which continuous-streamflow and specific-conductance data were available for WY 2019. Daily flow-weighted concentrations of chloride and sodium were calculated by multiplying instantaneous flows by concurrent concentrations of chloride and sodium (estimated from measurements of specific conductance) for each day and dividing the sum by the total flow for that day. At the four instrumented monitoring stations, where continuous flow was unavailable (table 1), daily mean concentrations of chloride and sodium were calculated from the daily mean value of specific conductance for each day. The latter method may result in less accurate concentrations because instantaneous measurements of specific conductance may change (decrease or increase) with surface-water runoff; however, the variability of instantaneous measurements of specific conductance at these streamgages was generally small and daily mean values did not differ substantially from daily flow-weighted values estimated during prior water years when instantaneous flow data were available. Daily loads of chloride and sodium were estimated by multiplying daily flowweighted concentrations of chloride and sodium (in milligrams per liter) by daily discharge (in liters per day). Daily data were summed to estimate monthly or annual loads.

Daily loads of water-quality constituents (in samples collected by the PWSB) were calculated for all sampling dates during WY 2019 (table 4, in back of report) for which periodic- or continuous-streamflow data were available (table 1). These loads were calculated by multiplying constituent concentrations (in milligrams or colony forming units per liter) in single samples by the daily discharge (in liters per day) for the day on which each sample was collected. The flows, which in some cases were estimates, were assumed to be representative of the flow at the time of the sample collection. Loads (in million colony forming units per day, kilograms per day, or grams per day) and yields (in million colony forming units per day per square mile, kilograms per day per square mile, or grams per day per square mile) were calculated for bacteria, chloride, nitrite, nitrate, and orthophosphate. Censored data (concentrations reported as less than method detection limits) were replaced with concentrations equal to one-half the method detection limit.

\section{Streamflow}

Monitoring streamflow is a necessary step to measure the volume of water and estimate constituent loads to the Scituate Reservoir. The Ponaganset River is the largest monitored tributary to the Scituate Reservoir. Mean annual streamflow at the streamgage on the Ponaganset River (01115187, PWSB station 35) for the entire period of its operation (mean of the annual mean streamflows for the period of record, WYs 1994-2018) before WY 2019 was about 29 cubic feet per second ( $\mathrm{ft}^{3} / \mathrm{s}$; U.S. Geological Survey, 2020). During WY 2019, the annual mean streamflow of $40 \mathrm{ft}^{3} / \mathrm{s}$ was substantially greater (within the 95th percentile of all annual mean streamflows; fig. 3) than the long-term mean annual streamflows for the period of record and slightly less than that highest annual mean streamflow recorded for WY 2006 $\left(41.5 \mathrm{ft}^{3} / \mathrm{s}\right.$; U.S. Geological Survey, 2020). The daily mean streamflow was greater than the median streamflows for much of WY 2019 and greater than the 90th percentile of the daily mean streamflows for the period of record (fig. 3) for many days in October, November, December, January, April, May, and August.

The mean annual streamflow at the Peeptoad Brook streamgage (01115098; PWSB station 16), the other long-term continuous-record streamgage in the Scituate Reservoir drainage area, for the period of record (WYs 1994-2018) before WY 2019 was $10.4 \mathrm{ft}^{3} / \mathrm{s}$ (U.S. Geological Survey, 2020). The annual mean streamflow at the Peeptoad Brook streamgage during WY 2019 also was greater than the mean annual streamflow for its period of record at $13 \mathrm{ft}^{3} / \mathrm{s}$. 
A

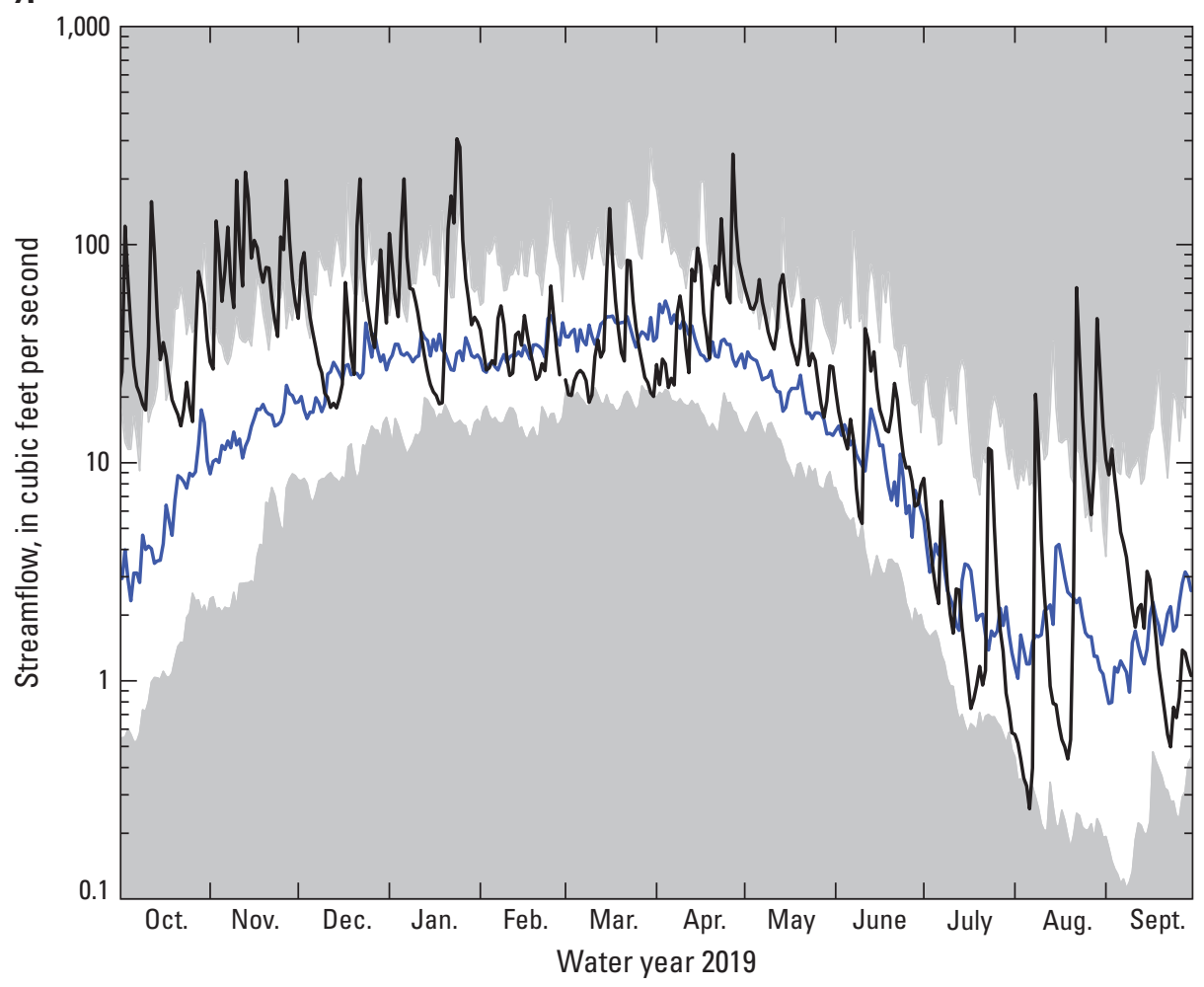

$B$

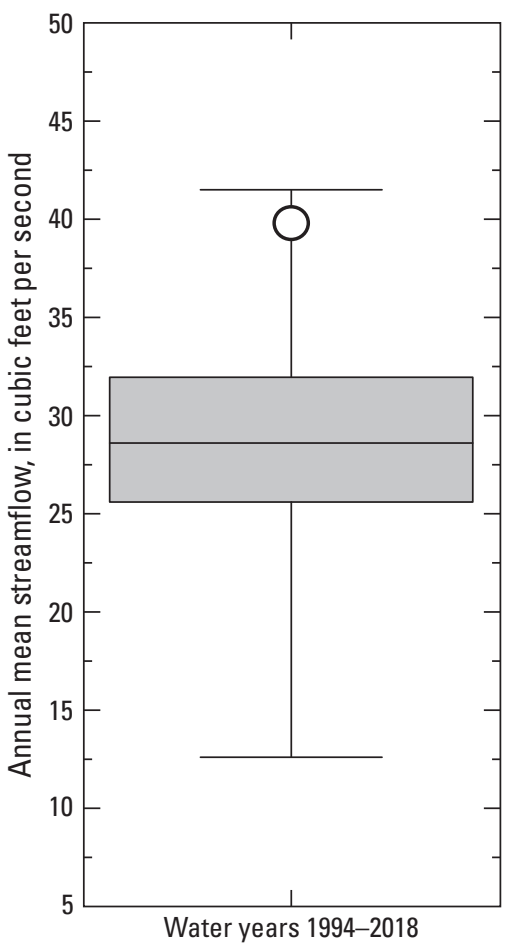

EXPLANATION

Unshaded area shows the range between the 10th and 90th percentile values of daily streamflow, water years 1994-2018

Daily mean streamflow, water year 2019

Median daily streamflow, water years 1994-2018

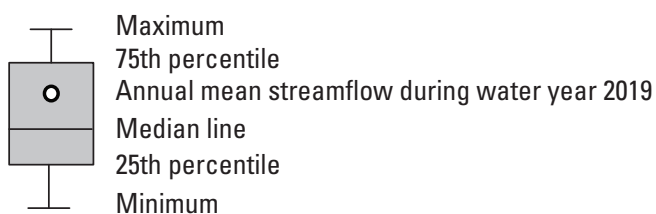

Figure 3. Hydrologic data taken at the U.S. Geological Survey continuous-record streamgage on the Ponaganset river at south Foster (01115187), in the Scituate Reservoir drainage area, Rhode Island; $A$, graph showing measured daily mean streamflow for 0 ctober 1 , 2018, through September 30, 2019, and the 10th percentile, median, and 90th percentile values of daily streamflow for 0ctober 1, 1994, through September 30, 2018; and B, box plot showing annual mean streamflow during water year 2019 and the distribution of mean annual streamflows for water years 1994-2018. Location of station is shown on figure 1.

\section{Water Quality and Constituent Loads and Yields}

Water-quality conditions in the Scituate Reservoir drainage area are described by summary statistics for water-quality properties, constituent concentrations, and estimated constituent loads and yields. Loads and yields measure the rates at which masses of constituents are transferred to the reservoir by tributaries. Tributaries with high flows tend to have high loads because the greater volume of water can carry more of the constituent to the reservoir per unit time than tributaries with low flows. Yield represents the constituent load per unit of drainage area and is calculated by dividing the load estimated for a streamgage by the drainage area for the monitoring station. Yields are useful for comparison among streamgages that have different drainage areas because the basin size and therefore total streamflow volume are normalized. Yields also are useful for examining potential differences among basin properties that may contribute to water quality in the reservoir.

Summary statistics include means and medians. For some purposes, median values are more appropriate because they are less likely to be affected by high or low concentrations (or outliers). Medians are especially important to use for summarizing a relatively limited number of values. In contrast, continuously monitored streamflow and loads of chloride and sodium (estimated from measurements of specific conductance), datasets that include a large number of values, are better summarized in terms of means because large datasets are more resistant to the effects of outliers than small datasets. Mean values also are particularly appropriate for measuring loads because outlier values, which typically represent large flows, are important to include in estimates of constituent masses delivered to receiving waters. 
Uncertainties associated with measuring streamflow and specific conductance and with chloride and sodium sample collection, preservation, and analysis produce uncertainties in load and yield estimates. The load and yield estimates presented in the text and tables are the most likely values for chloride and sodium inputs from tributaries or their drainage basins, based on the available data and analysis methods. It may be best to discuss loads and yields in terms of a range within which the true values lie; however, the most likely values of loads and yields are presented for ease of discussion and presentation. The range within which the true values lie depends on the uncertainties in individual measurements of streamflow and concentration, which are difficult to quantify with the available information. The uncertainties associated with streamflow are commonly assumed to affect load and yield calculations more than the errors associated with measuring specific conductance or chemical analysis, and the uncertainties associated with estimated streamflow are greater than those associated with measured streamflow. The most likely values of loads and yields presented in the tables and text are sufficient for planning-level analysis of water quality in tributaries and their drainage basins.

\section{Chloride and Sodium Loads and Yields Estimated from Specific-Conductance Monitoring Data}

Chloride and sodium are constituents of special concern in the Scituate Reservoir drainage area; they are major constituents of road salt used for deicing, and several major roadways cross the drainage basin. State Routes 12 and 14 cut across the main body of the reservoir, and Route 116 parallels the eastern limb (fig. 1). Nimiroski and Waldron (2002) indicated that tributaries in basins with State-maintained roads had substantially higher concentrations of chloride and sodium than tributaries in basins with low road density, presumably because of deicing activities. In addition, sodium is a constituent of potential concern for human health; some persons on restricted diets might need to limit intake of sodium.

Estimated monthly mean ${ }^{2}$ chloride concentrations in tributaries of the Scituate Reservoir drainage area ranged from 7.9 to 83 milligrams per liter $(\mathrm{mg} / \mathrm{L})$, and estimated monthly mean sodium concentrations ranged from 5.4 to $47 \mathrm{mg} / \mathrm{L}$ (table 5). The highest monthly mean concentrations of chloride and sodium were estimated to be 83 and $47 \mathrm{mg} / \mathrm{L}$, respectively, at unnamed tributary to Regulating Reservoir (unnamed brook A; 01115120; PWSB station 18) in July 2019. The estimated monthly mean concentrations at most stations were greater during the months of July and August compared with the estimated monthly mean concentrations during the winter months. Peak estimated monthly mean concentrations for Cork Brook and Huntinghouse Brook (01115280 and 01115110 , respectively; PWSB stations 3 and 14, respectively) occurred

\footnotetext{
${ }^{2}$ Monthly mean concentrations were calculated by dividing the total monthly load by the total discharge for the month.
}

in September, and estimated monthly mean concentrations for Peeptoad Brook (01115098; PWSB station 16), Moswansicut Reservoir (01115170; PWSB station 19), and Dolly Cole Brook (01115190; PWSB station 24) peaked in the beginning of the WY in October 2019. The highest annual mean ${ }^{3}$ concentrations of chloride and sodium were estimated to be 59 and $35 \mathrm{mg} / \mathrm{L}$, respectively, at the Moswansicut Reservoir (table 6). The relatively high annual mean concentrations of chloride and sodium at Bear Tree Brook (01115275; PWSB station 9; 48 and $28 \mathrm{mg} / \mathrm{L}$, respectively) are the result of residual chloride and sodium leaching to groundwater from a formerly uncovered salt storage pile (Nimiroski and Waldron, 2002) and comparatively small surface-water flows. Annual mean concentrations of chloride and sodium, ranging from 32 to $52 \mathrm{mg} / \mathrm{L}$ and 20 to $30 \mathrm{mg} / \mathrm{L}$, respectively, estimated at the unnamed tributary to the Regulating Reservoir (unnamed brook A; 01115120; PWSB station 18) and Peeptoad Brook also were relatively high (table 6). These stations are in the more developed, northeastern part of the Scituate Reservoir drainage area (fig. 1), which also includes the Moswansicut Reservoir.

During WY 2019, the Scituate Reservoir received about 3,500 metric tons ( $t$; about 3,800 short tons) of chloride and $2,100 \mathrm{t}$ (about 2,300 short tons) of sodium from tributaries that are equipped with instrumentation capable of continuously monitoring specific conductance (table 6). The highest annual chloride and sodium loads in the drainage area during WY 2019 were estimated to be 620 and $380 \mathrm{t}$, respectively, at the Ponaganset River station (table 6). Monthly estimated chloride and sodium loads were highest in November (table 7), corresponding to some of the highest sustained flows during this monitoring period (fig. 3). The monthly estimated chloride and sodium loads for this month accounted for between 14 and 22 percent of the annual load at each station. From January through April, the winter period when surface-water runoff often contains elevated concentrations of roadway deicing compounds, the sum of the monthly loads of chloride and sodium at each station accounted for between 41 and 54 percent of the annual load at each station and about 45 percent of the annual load for the monitored area in the Scituate Reservoir drainage area. The highest annual chloride and sodium yields were 180 and 100 metric tons per square mile, respectively, measured at unnamed tributary to Regulating Reservoir (unnamed brook A; 01115120; PWSB station 18; table 6). Chloride and sodium yields also were comparatively high at Bear Tree Brook (PWSB station 9) at 150 and 89 metric tons per square mile, respectively. During WY 2019 , estimated annual loads of chloride and sodium at the continuous monitoring stations were greater than the median annual loads for WYs 2009-18 at all stations, and for 9 of the 14 stations, the annual loads were greater than the maximum annual loads for WYs 2009-18 (fig. 4). Estimated annual loads of chloride and sodium for the monitored area in the Scituate Reservoir drainage area during WY 2019 were greater

\footnotetext{
${ }^{3}$ Annual mean concentrations were calculated by dividing the total annual load by the total discharge for the year.
} 
than loads estimated during the previous water year (Smith, 2019a). The estimated annual loads for the last three consecutive WYs were the highest for the period of record since WY 2009 (fig. 5).

The estimated annual mean yields of chloride and sodium for the drainage areas upstream from the 14 USGS continuous-record streamgages, which represent nearly 66 percent of the Scituate Reservoir drainage area, were 56 and 34 metric tons per year per square mile $\left(\mathrm{t} / \mathrm{y} / \mathrm{mi}^{2}\right)$, respectively. These estimated annual mean yields of chloride and sodium for WY 2019 were greater than the yields in WY 2018 (49 and $30 \mathrm{t} / \mathrm{y} / \mathrm{mi}^{2}$, respectively; Smith, 2019a) and higher than those previously estimated since WY 2009 (fig. 5).

\section{Physical and Chemical Properties and Daily Loads and Yields Estimated from Data Collected by the Providence Water Supply Board}

\section{Physical and Chemical Properties}

Physical and chemical properties, including $\mathrm{pH}$, turbidity, alkalinity, and color, were routinely measured to determine water quality in each of the six subbasins in the Scituate Reservoir drainage area (table 8 ) by the PWSB. Specifically, $\mathrm{pH}$ is a measure of the acidity of the water, color can be an indirect measure of the amount of organic carbon dissolved in the water column, turbidity is an indirect measure of suspended particles, and alkalinity is a measure of the acidneutralizing capacity of water.

The median $\mathrm{pH}$ in tributaries in the Scituate Reservoir drainage area ranged from 5.8 to 7.0; the median of the medians for all stations was 6.4. Median values of color ranged from 18 to 180 platinum cobalt units; the median for all stations was 50 platinum cobalt units. Median values of turbidity ranged from 0.17 to 1.5 nephelometric turbidity units; the median for all stations was 0.59 nephelometric turbidity units. Median alkalinity values in tributaries were low, ranging from 3.1 to $20 \mathrm{mg} / \mathrm{L}$ as calcium carbonate $\left(\mathrm{CaCO}_{3}\right)$; the median for all stations was $5.9 \mathrm{mg} / \mathrm{L}$ as $\mathrm{CaCO}_{3}$ (table 8).

\section{Constituent Concentrations and Daily Loads and Yields}

Fecal indicator bacteria, chloride, and nutrients such as nitrogen and phosphorus are commonly detected in natural water; at elevated concentrations, these constituents can cause or contribute to water-quality impairments. Fecal indicator bacteria, which are found in the intestines of warm-blooded animals, may indicate impairment from sewage contamination or from livestock or wildlife that defecate in or near the stream margin. Chloride originates in tributary stream water from precipitation, weathering, or human activities such as waste disposal, use of septic systems, and road deicing. Sources of nutrients in tributary stream water include atmospheric deposition, leaching of naturally occurring organic material, discharge of groundwater that is enriched with nutrients from septic-system leachate, and runoff contaminated with fertilizer or animal waste. The ultimate intended use of water in the tributaries is drinking water, which must meet specific waterquality standards. For this reason, the PWSB closely monitors concentrations of these constituents in tributaries. Median concentrations, loads, and yields of water-quality constituents are listed in tables 8,9 and 10 .

\section{Bacteria}

Median concentrations of total coliform bacteria were above the detection limit (1 colony forming unit per 100 milliliters [CFU/100 mL]) at all sites (table 8). Median concentrations of $E$. coli were equal to or greater than a detection limit of $10 \mathrm{CFU} / 100 \mathrm{~mL}$ (highest detection limit of median values) at 25 of the 37 stations; however, censored median concentrations of $E$. coli less than $10 \mathrm{CFU} / 100 \mathrm{~mL}$ were available at 12 stations. Total coliform bacteria concentrations were greater than $E$. coli concentrations (as expected because total coliform is more inclusive than $E$. coli); the medians of median concentrations for all sites in the drainage area were 1,000 CFU/100 $\mathrm{mL}$ for total coliform bacteria and $10 \mathrm{CFU} / 100 \mathrm{~mL}$ for $E$. coli (table 8). The highest median concentration of total coliform bacteria, 7,500 CFU/100 mL, was at unnamed tributary \#2 to Moswansicut Reservoir (01115165; PWSB station 21) in the Moswansicut Reservoir subbasin. Median concentrations of total coliform bacteria exceeded 2,000 CFU/100 mL at five other stations including Spruce Brook (01115184; PWSB station 5), Bear Tree Brook (01115275; PWSB station 9), unnamed tributary \#4 to Scituate Reservoir (01115350; PWSB station 30), and unnamed tributary to Regulating Reservoir (01115120; PWSB station 18). Median concentrations of total coliform bacteria were lowest at Moswansicut Reservoir (01115170; PWSB station 19).

Median daily loads and yields of total coliform bacteria and $E$. coli varied by about two orders of magnitude (tables 9 and 10). The median daily loads of total coliform bacteria for all subbasins in the Scituate Reservoir drainage area ranged from 11,000 to 600,000 million colony forming units per day $\left(\mathrm{CFU} \times 10^{6} / \mathrm{d}\right)$, and yields ranged from 8,600 to 230,000 million colony forming units per day per square mile $\left(\mathrm{CFU} \times 10^{6} / \mathrm{d} / \mathrm{mi}^{2}\right) ; E$. coli loads ranged from 130 to $12,000 \mathrm{CFU} \times 10^{6} / \mathrm{d} /$, and yields ranged from 260 to $3,700 \mathrm{CFU} \times 10^{6} / \mathrm{d} / \mathrm{mi}^{2}$ (table 9 ). The highest median daily yield of total coliform bacteria at $230,000 \mathrm{CFU} \times 10^{6} / \mathrm{d} / \mathrm{mi}^{2}$ was at Ponaganset River (01115187; PWSB station 35 ), and the highest median daily yield of $E$. coli of $3,700 \mathrm{CFU} \times 10^{6} / \mathrm{d} / \mathrm{mi}^{2}$ occurred at the unnamed tributary to Regulating Reservoir (PWSB station 18; table 10). Although relatively high for sampling stations in the Scituate Reservoir subbasin, median daily bacteria yields at these stations were low to moderate for yields of indicator bacteria in sewagecontaminated stream water or stream water affected by stormwater runoff in an urban environment (Breault and others, 2002). 
Table 5. Monthly mean concentrations of chloride and sodium estimated from continuous measurements of specific conductance in the Scituate Reservoir drainage area, Rhode Island, October 1, 2018, through September 30, 2019.

[Alternate station names are listed in parentheses for stations where different historical names were used for the same sampling location by the Providence Water Supply Board (PWSB). Locations of stations are shown on figure 1. Monthly mean concentrations were calculated by dividing the monthly load by the total discharge for the month. USGS, U.S. Geological Survey; Cl, chloride; Na, sodium; mg/L, milligram per liter; —, not applicable]

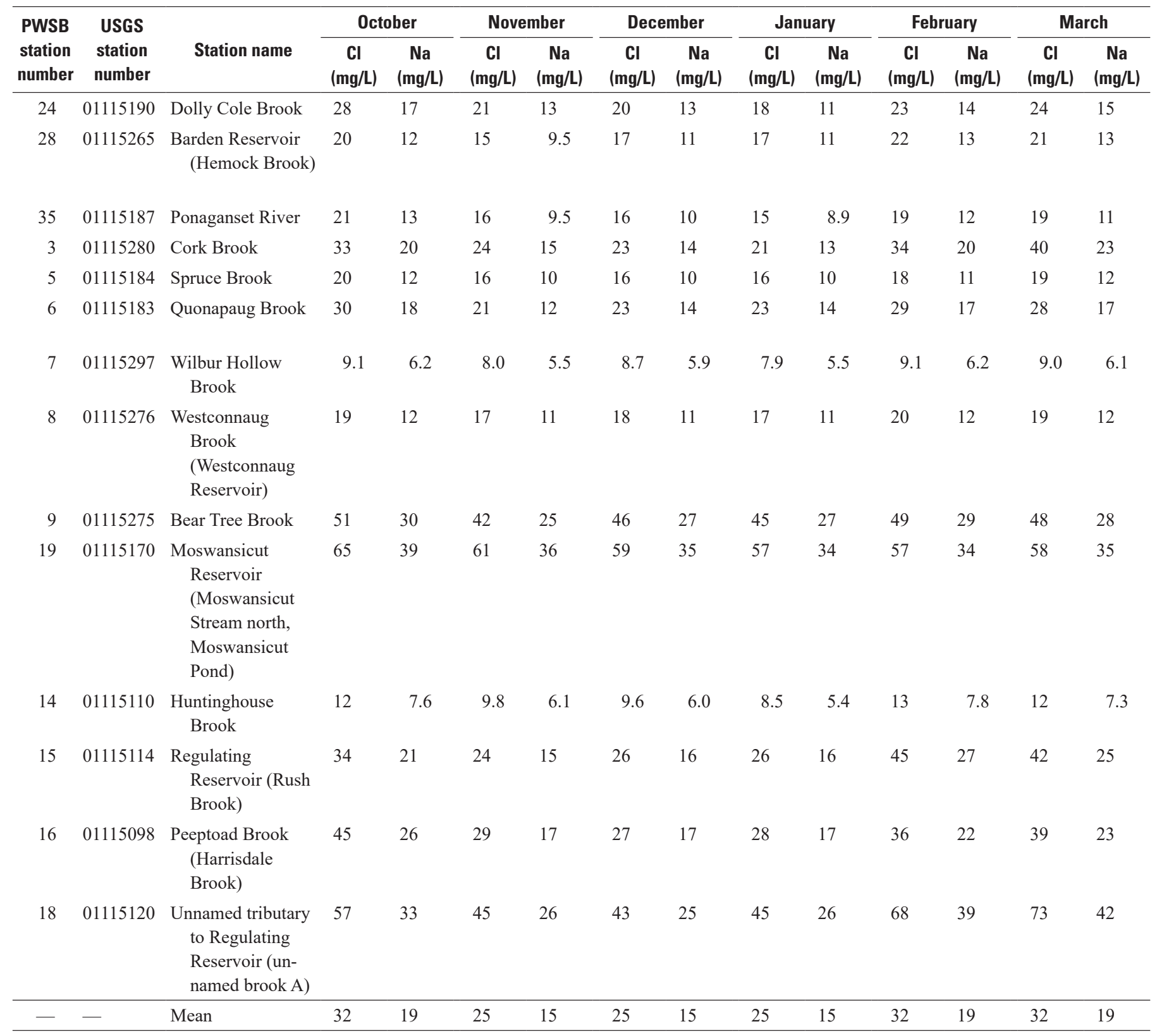


Table 5. Monthly mean concentrations of chloride and sodium estimated from continuous measurements of specific conductance in the Scituate Reservoir drainage area, Rhode Island, October 1, 2018, through September 30, 2019._Continued

[Alternate station names are listed in parentheses for stations where different historical names were used for the same sampling location by the Providence Water Supply Board (PWSB). Locations of stations are shown on figure 1. Monthly mean concentrations were calculated by dividing the monthly load by the total discharge for the month. USGS, U.S. Geological Survey; Cl, chloride; Na, sodium; mg/L, milligram per liter; —, not applicable]

\begin{tabular}{|c|c|c|c|c|c|c|c|c|c|c|c|c|c|c|}
\hline \multirow{2}{*}{$\begin{array}{l}\text { PWSB } \\
\text { station } \\
\text { number }\end{array}$} & \multirow{2}{*}{$\begin{array}{l}\text { USGS } \\
\text { station } \\
\text { number }\end{array}$} & \multirow[b]{2}{*}{ Station name } & \multicolumn{2}{|c|}{ April } & \multicolumn{2}{|c|}{ May } & \multicolumn{2}{|c|}{ June } & \multicolumn{2}{|c|}{ July } & \multicolumn{2}{|c|}{ August } & \multicolumn{2}{|c|}{ September } \\
\hline & & & $\begin{array}{c}\mathrm{Cl} \\
(\mathrm{mg} / \mathrm{L})\end{array}$ & $\underset{(\mathrm{mg} / \mathrm{L})}{\mathrm{Na}}$ & $\underset{(\mathrm{mg} / \mathrm{L})}{\mathrm{Cl}}$ & $\underset{(\mathrm{mg} / \mathrm{L})}{\mathrm{Na}}$ & $\begin{array}{c}\mathrm{Cl} \\
(\mathrm{mg} / \mathrm{L})\end{array}$ & $\begin{array}{c}\mathrm{Na} \\
(\mathrm{mg} / \mathrm{L})\end{array}$ & $\underset{(\mathrm{mg} / \mathrm{L})}{\mathrm{Cl}}$ & $\underset{(\mathrm{mg} / \mathrm{L})}{\mathrm{Na}}$ & $\underset{(\mathrm{mg} / \mathrm{L})}{\mathrm{Cl}}$ & $\begin{array}{c}\mathrm{Na} \\
(\mathrm{mg} / \mathrm{L})\end{array}$ & $\begin{array}{c}\mathrm{Cl} \\
(\mathrm{mg} / \mathrm{L})\end{array}$ & $\begin{array}{c}\mathrm{Na} \\
(\mathrm{mg} / \mathrm{L})\end{array}$ \\
\hline 24 & 01115190 & Dolly Cole Brook & 22 & 13 & 21 & 13 & 24 & 15 & 26 & 16 & 28 & 17 & 28 & 17 \\
\hline 28 & 01115265 & $\begin{array}{l}\text { Barden Reservoir } \\
\quad \text { (Hemock Brook) }\end{array}$ & 18 & 11 & 19 & 12 & 25 & 15 & 33 & 20 & 36 & 21 & 35 & 21 \\
\hline 3 & 01115280 & Cork Brook & 31 & 18 & 29 & 18 & 33 & 20 & 37 & 22 & 43 & 25 & 55 & 31 \\
\hline 5 & 01115184 & Spruce Brook & 18 & 11 & 19 & 12 & 21 & 13 & 28 & 16 & 40 & 22 & 39 & 22 \\
\hline 6 & 01115183 & Quonapaug Brook & 26 & 15 & 25 & 15 & 31 & 18 & 39 & 24 & 52 & 31 & 47 & 28 \\
\hline 7 & 01115297 & Wilbur Hollow Brook & 8.5 & 5.8 & 8.9 & 6.1 & 9.5 & 6.4 & 10 & 6.7 & 12 & 7.9 & 11 & 7.4 \\
\hline 9 & 01115275 & Bear Tree Brook & 44 & 26 & 49 & 29 & 54 & 32 & 65 & 39 & 67 & 40 & 67 & 40 \\
\hline 19 & 01115170 & $\begin{array}{l}\text { Moswansicut } \\
\text { Reservoir } \\
\text { (Moswansicut } \\
\text { Stream north, } \\
\text { Moswansicut } \\
\text { Pond) }\end{array}$ & 56 & 33 & 56 & 33 & 57 & 34 & 58 & 34 & 57 & 34 & 57 & 34 \\
\hline 14 & 01115110 & Huntinghouse Brook & 10 & 6.3 & 12 & 7.3 & 13 & 7.9 & 15 & 9.2 & 13 & 8.2 & 16 & 9.5 \\
\hline- & - & Mean & 28 & 17 & 30 & 18 & 33 & 20 & 40 & 24 & 39 & 23 & 41 & 24 \\
\hline
\end{tabular}


Table 6. Annual mean chloride and sodium concentrations, loads, and yields for sampling stations in the Scituate Reservoir drainage area, Rhode Island, from October 1, 2018, through September 30, 2019.

[Alternate station names are listed in parentheses for stations where different historical names were used for the same sampling location by the Providence Water Supply Board (PWSB). Locations of stations are shown on figure 1. Annual mean concentrations were calculated by dividing the annual load by the total discharge for the year; annual mean yields were calculated by dividing the sum of individual loads by the sum of the drainage area. USGS, U.S. Geological Survey; $\mathrm{Cl}$, chloride; $\mathrm{Na}$, sodium; $\mathrm{mg} / \mathrm{L}$, milligram per liter; $\mathrm{t} / \mathrm{yr}$, metric tons per year; $\mathrm{t} / \mathrm{yr} / \mathrm{mi}^{2}$, metric tons per year per square mile; —, not applicable ]

\begin{tabular}{|c|c|c|c|c|c|c|c|c|}
\hline \multirow{2}{*}{$\begin{array}{c}\text { PWSB } \\
\text { station } \\
\text { number }\end{array}$} & \multirow{2}{*}{$\begin{array}{c}\text { USGS } \\
\text { station } \\
\text { number }\end{array}$} & \multirow[b]{2}{*}{ Station name } & \multicolumn{2}{|c|}{ Concentration } & \multicolumn{2}{|c|}{ Load } & \multicolumn{2}{|c|}{ Yield } \\
\hline & & & $\underset{(\mathrm{mg} / \mathrm{L})}{\mathrm{Cl}}$ & $\underset{(\mathrm{mg} / \mathrm{L})}{\mathrm{Na}}$ & $\begin{array}{c}\mathrm{CI} \\
(\mathrm{t} / \mathrm{yr})\end{array}$ & $\begin{array}{c}\mathrm{Na} \\
(\mathrm{t} / \mathrm{yr})\end{array}$ & $\begin{array}{c}\mathrm{Cl} \\
\left(\mathrm{t} / \mathrm{yr} / \mathrm{mi}^{2}\right)\end{array}$ & $\underset{\left(t / y r / \mathrm{mi}^{2}\right)}{\mathrm{Na}}$ \\
\hline 24 & 01115190 & Dolly Cole Brook & 22 & 13 & 300 & 180 & 61 & 38 \\
\hline 28 & 01115265 & $\begin{array}{l}\text { Barden Reservoir } \\
\quad \text { (Hemlock Brook) }\end{array}$ & 18 & 11 & 420 & 260 & 48 & 30 \\
\hline \multicolumn{9}{|c|}{ Direct runoff subbasin } \\
\hline 3 & 01115280 & Cork Brook & 28 & 17 & 130 & 76 & 67 & 41 \\
\hline 5 & 01115184 & Spruce Brook & 19 & 12 & 49 & 30 & 39 & 24 \\
\hline 6 & 01115183 & Quonapaug Brook & 25 & 15 & 130 & 79 & 68 & 40 \\
\hline 9 & 01115275 & Bear Tree Brook & 48 & 28 & 93 & 55 & 150 & 89 \\
\hline \multicolumn{9}{|c|}{ Moswansicut Reservoir subbasin } \\
\hline 19 & 01115170 & $\begin{array}{l}\text { Moswansicut } \\
\text { Reservoir, } \\
\text { (Moswansicut } \\
\text { Stream north, } \\
\text { Moswansicut Pond) }\end{array}$ & 59 & 35 & 460 & 270 & 140 & 84 \\
\hline \multicolumn{9}{|c|}{ Regulating Reservoir subbasin } \\
\hline 14 & 01115110 & Huntinghouse Brook & 11 & 6.5 & 160 & 100 & 26 & 16 \\
\hline \multicolumn{9}{|c|}{ Scituate Reservoir drainage area } \\
\hline - & - & $\begin{array}{l}\text { Mean concentration or } \\
\text { yield }\end{array}$ & 28 & 17 & - & - & 56 & 34 \\
\hline- & - & Total load & - & - & 3,500 & 2,100 & - & - \\
\hline
\end{tabular}




\section{Chloride and Sodium}

Median chloride concentrations among the PWSB stations ranged from 7.2 to $170 \mathrm{mg} / \mathrm{L}$; the highest concentration was measured in Toad Pond (PWSB station 31; table 8). The median of median concentrations for all sites in the drainage area was $25.1 \mathrm{mg} / \mathrm{L}$ (table 8). Median daily chloride loads and yields estimated from samples collected by the PWSB varied among monitoring stations in the drainage area (tables 9 and 10). Ponaganset River (01115187; PWSB station 35) had the largest median daily chloride load at 1,900 kilograms per day (table 9). The largest median daily chloride yield was determined to be $540 \mathrm{~kg} / \mathrm{d} / \mathrm{mi}^{2}$ at Bear Tree Brook (01115275; PWSB station 9; table 10). The median daily chloride yield for monitored areas within the drainage area was 140 kilograms per day per square mile $\left(\mathrm{kg} / \mathrm{d} / \mathrm{mi}^{2}\right)$.

\section{Nutrients}

Median concentrations of nitrite and nitrate (table 8) were 0.001 and $0.08 \mathrm{mg} / \mathrm{L}$ as nitrogen $(\mathrm{N})$, respectively. The highest median concentration of nitrite was $0.004 \mathrm{mg} / \mathrm{L}$ as $\mathrm{N}$ measured in a sample collected at unnamed tributary to Regulating Reservoir (01115120; PWSB station 18). The highest median concentration of nitrate $(0.85 \mathrm{mg} / \mathrm{L}$ as $\mathrm{N})$ was measured in a sample collected at the Moswansicut
Reservoir (Moswansicut Stream south; 01115167; PWSB station 22). The median concentration of orthophosphate for the entire study area (table 8) was $0.03 \mathrm{mg} / \mathrm{L}$ as phosphate $\left(\mathrm{PO}_{4}\right)$. The maximum median concentration of orthophosphate was $0.11 \mathrm{mg} / \mathrm{L}$ as $\mathrm{PO}_{4}$ measured in a sample collected at unnamed tributary \#1 to Moswansicut Reservoir (01115160; PWSB station 20). Median daily nitrite loads were largest at Ponaganset River (01115187; PWSB station 35) at 93 grams per day (g/d; table 9$)$. Median daily nitrate loads were largest at Bear Tree Brook (01115275; PWSB station 9) at 3,000 g/d as N. Despite the relatively small flows at Bear Tree Brook, the median nitrate concentration for samples collected at this station was high $(0.49 \mathrm{mg} / \mathrm{L}$ as $\mathrm{N})$ compared to other PWSB stations (table 8). Median daily orthophosphate loads were largest (2,900 g/d as $\left.\mathrm{PO}_{4}\right)$ at Barden Reservoir (01115165; PWSB station 28; table 10). The largest median daily yields for nitrite and nitrate were 17 grams per day per square mile $\left(\mathrm{g} / \mathrm{d} / \mathrm{mi}^{2}\right)$ as $\mathrm{N}$ and $4,800 \mathrm{~g} / \mathrm{d} / \mathrm{mi}^{2}$ as $\mathrm{N}$, respectively, at Bear Tree Brook; and the largest median daily yield for orthophosphate was $560 \mathrm{~g} / \mathrm{d} / \mathrm{mi}^{2}$ as $\mathrm{PO}_{4}$ at unnamed brook south of Westconnaug Reservoir (01115273; PWSB station 11; table 10). The medians of median daily loads and yields were $18 \mathrm{~g} / \mathrm{d}$ and $6.8 \mathrm{~g} / \mathrm{d} / \mathrm{mi}^{2}$ for nitrite as $\mathrm{N}, 1,000 \mathrm{~g} / \mathrm{d}$ and $440 \mathrm{~g} / \mathrm{d} / \mathrm{mi}^{2}$ for nitrate as $\mathrm{N}$, and $410 \mathrm{~g} / \mathrm{d}$ and $140 \mathrm{~g} / \mathrm{d} / \mathrm{mi}^{2}$ for orthophosphate as $\mathrm{PO}_{4}$, respectively. 
Table 7. Monthly estimated chloride and sodium loads by sampling station, in the Scituate Reservoir drainage area, Rhode Island, October 1, 2018, through September 30, 2019.

[Alternate station names are listed in parentheses for stations where different historical names were used for the same sampling location by the Providence Water Supply Board (PWSB). Locations of stations are shown on figure 1. USGS, U.S. Geological Survey; Cl, chloride; Na, sodium; t, metric ton; - , not applicable]

\begin{tabular}{|c|c|c|c|c|c|c|c|c|c|c|c|c|c|c|}
\hline \multirow{2}{*}{$\begin{array}{l}\text { PWSB } \\
\text { station } \\
\text { number }\end{array}$} & \multirow{2}{*}{$\begin{array}{c}\text { USGS } \\
\text { station } \\
\text { number }\end{array}$} & \multirow[b]{2}{*}{ Station name } & \multicolumn{2}{|c|}{ October } & \multicolumn{2}{|c|}{ November } & \multicolumn{2}{|c|}{ December } & \multicolumn{2}{|c|}{ January } & \multicolumn{2}{|c|}{ February } & \multicolumn{2}{|c|}{ March } \\
\hline & & & $\begin{array}{l}\text { Cl } \\
\text { (t) }\end{array}$ & $\begin{array}{c}\mathrm{Na} \\
\text { (t) }\end{array}$ & $\begin{array}{l}\text { CI } \\
(t)\end{array}$ & $\begin{array}{c}\mathrm{Na} \\
(\mathrm{t})\end{array}$ & $\begin{array}{l}\text { CI } \\
\text { (t) }\end{array}$ & $\begin{array}{c}\mathrm{Na} \\
\text { (t) }\end{array}$ & $\begin{array}{l}\text { Cl } \\
(t)\end{array}$ & $\begin{array}{c}\mathrm{Na} \\
(\mathrm{t})\end{array}$ & $\begin{array}{l}\text { CI } \\
(t)\end{array}$ & $\begin{array}{c}\mathrm{Na} \\
(\mathrm{t})\end{array}$ & $\begin{array}{l}\text { Cl } \\
(t)\end{array}$ & $\begin{array}{c}\mathrm{Na} \\
\text { (t) }\end{array}$ \\
\hline 24 & 01115190 & Dolly Cole Brook & 37 & 22 & 61 & 38 & 36 & 22 & 50 & 31 & 20 & 13 & 26 & 16 \\
\hline 28 & 01115265 & Barden Reservoir (Hemock Brook) & 48 & 30 & 71 & 46 & 60 & 38 & 52 & 33 & 39 & 24 & 48 & 29 \\
\hline 35 & 01115187 & Ponaganset River & 64 & 39 & 110 & 64 & 63 & 38 & 92 & 55 & 45 & 28 & 57 & 35 \\
\hline 3 & 01115280 & Cork Brook & 15 & 9.1 & 24 & 15 & 13 & 8.3 & 14 & 8.8 & 9.1 & 5.4 & 15 & 8.9 \\
\hline 5 & 01115184 & Spruce Brook & 4.9 & 2.9 & 6.8 & 4.3 & 5.0 & 3.1 & 5.7 & 3.6 & 4.1 & 2.5 & 5.1 & 3.1 \\
\hline 6 & 01115183 & Quonapaug Brook & 15 & 8.7 & 24 & 14 & 15 & 8.8 & 18 & 10 & 12 & 7.1 & 15 & 8.6 \\
\hline 7 & 01115297 & Wilbur Hollow Brook & 8.8 & 6.0 & 16 & 11 & 11 & 7.3 & 11 & 7.7 & 7.6 & 5.2 & 9.2 & 6.3 \\
\hline 8 & 01115276 & Westconnaug Brook (Westconnaug Reservoir) & 17 & 11 & 33 & 21 & 25 & 16 & 28 & 18 & 18 & 11 & 20 & 12 \\
\hline 9 & 01115275 & Bear Tree Brook & 7.6 & 4.5 & 14 & 8.2 & 11 & 6.3 & 12 & 7.2 & 7.5 & 4.4 & 8.3 & 4.9 \\
\hline 19 & 01115170 & $\begin{array}{l}\text { Moswansicut Reservoir (Moswansicut Stream north, } \\
\text { Moswansicut Pond) }\end{array}$ & 38 & 22 & 88 & 52 & 60 & 36 & 66 & 39 & 39 & 23 & 44 & 26 \\
\hline 14 & 01115110 & Huntinghouse Brook & 16 & 9.8 & 31 & 19 & 18 & 11 & 22 & 14 & 14 & 8.5 & 17 & 10 \\
\hline 15 & 01115114 & Regulating Reservoir (Rush Brook) & 37 & 23 & 55 & 34 & 34 & 21 & 41 & 26 & 31 & 19 & 47 & 29 \\
\hline 16 & 01115098 & Peeptoad Brook (Harrisdale Brook) & 37 & 21 & 61 & 37 & 29 & 18 & 51 & 31 & 38 & 22 & 52 & 31 \\
\hline 18 & 01115120 & $\begin{array}{l}\text { Unnamed tributary to Regulating Reservoir (unnamed } \\
\text { brook A) }\end{array}$ & 3.9 & 2.3 & 11 & 6.2 & 5.2 & 3.0 & 9.8 & 5.7 & 3.0 & 1.7 & 5.2 & 3.0 \\
\hline- & - & Total & 350 & 210 & 610 & 370 & 390 & 240 & 150 & 87 & 290 & 170 & 370 & 220 \\
\hline
\end{tabular}

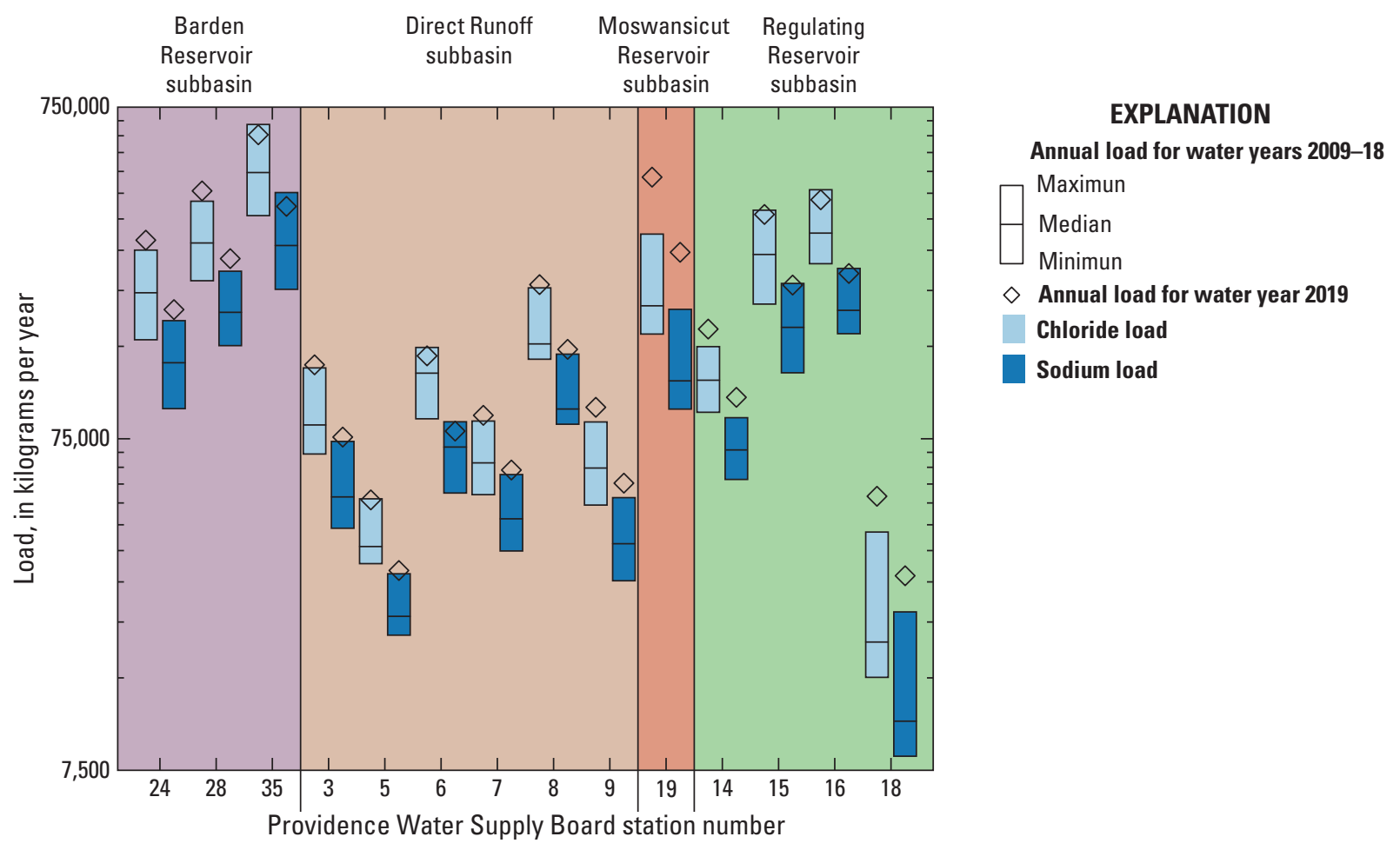

Figure 4. Annual loads of chloride and sodium estimated from streamflow and specific conductance data for water year 2019 and associated minimum, maximum, and median annual loads for water years 2009-18 at 14 Providence Water Supply Board sampling stations in the Scituate Reservoir drainage area, Rhode Island. Locations of continuous water-quality monitoring stations shown on figure 1. 
Table 7. Monthly estimated chloride and sodium loads by sampling station, in the Scituate Reservoir drainage area, Rhode Island, October 1, 2018, through September 30, 2019.-Continued

[Alternate station names are listed in parentheses for stations where different historical names were used for the same sampling location by the Providence Water Supply Board (PWSB). Locations of stations are shown on figure 1. USGS, U.S. Geological Survey; Cl, chloride; Na, sodium; t, metric ton; -, not applicable]

\begin{tabular}{|c|c|c|c|c|c|c|c|c|c|c|c|c|c|c|}
\hline \multirow{2}{*}{$\begin{array}{l}\text { PWSB } \\
\text { station } \\
\text { number }\end{array}$} & \multirow{2}{*}{$\begin{array}{c}\text { USGS } \\
\text { station } \\
\text { number }\end{array}$} & \multirow[b]{2}{*}{ Station name } & \multicolumn{2}{|c|}{ April } & \multicolumn{2}{|c|}{ May } & \multicolumn{2}{|c|}{ June } & \multicolumn{2}{|c|}{ July } & \multicolumn{2}{|c|}{ August } & \multicolumn{2}{|c|}{ September } \\
\hline & & & $\begin{array}{l}\mathrm{Cl} \\
(\mathrm{t})\end{array}$ & $\begin{array}{l}\mathrm{Na} \\
(t)\end{array}$ & $\begin{array}{l}\text { Cl } \\
(t)\end{array}$ & $\begin{array}{l}\mathrm{Na} \\
(\mathrm{t})\end{array}$ & $\begin{array}{l}\text { CI } \\
(t)\end{array}$ & $\begin{array}{l}\mathrm{Na} \\
(\mathrm{t})\end{array}$ & $\begin{array}{l}\mathrm{Cl} \\
(\mathrm{t})\end{array}$ & $\begin{array}{l}\mathrm{Na} \\
(\mathrm{t})\end{array}$ & $\begin{array}{l}\text { Cl } \\
\text { (t) }\end{array}$ & $\begin{array}{l}\mathrm{Na} \\
(\mathrm{t})\end{array}$ & $\begin{array}{l}\text { Cl } \\
(t)\end{array}$ & $\begin{array}{c}\mathrm{Na} \\
(\mathrm{t})\end{array}$ \\
\hline 24 & 01115190 & Dolly Cole Brook & 35 & 22 & 17 & 11 & 7.3 & 4.5 & 2.8 & 1.7 & 2.6 & 1.6 & 1.4 & 0.85 \\
\hline 28 & 01115265 & Barden Reservoir (Hemock Brook) & 49 & 31 & 28 & 17 & 11 & 6.5 & 5.6 & 3.3 & 4.3 & 2.5 & 2.9 & 1.7 \\
\hline 35 & 01115187 & Ponaganset River & 82 & 50 & 60 & 37 & 26 & 16 & 5.6 & 3.5 & 14 & 8.9 & 5.0 & 3.1 \\
\hline 3 & 01115280 & Cork Brook & 19 & 11 & 8.2 & 5.0 & 4.2 & 2.5 & 1.1 & 0.64 & 1.2 & 0.73 & 0.54 & 0.30 \\
\hline 5 & 01115184 & Spruce Brook & 6.0 & 3.7 & 4.2 & 2.6 & 2.4 & 1.4 & 1.1 & 0.65 & 2.6 & 1.4 & 1.4 & 0.77 \\
\hline 6 & 01115183 & Quonapaug Brook & 16 & 9.5 & 9.4 & 5.6 & 6.1 & 3.7 & 1.4 & 0.86 & 1.2 & 0.71 & 1.5 & 0.90 \\
\hline 7 & 01115297 & Wilbur Hollow Brook & 10 & 7.1 & 7.1 & 4.8 & 4.2 & 2.8 & 0.99 & 0.66 & 0.75 & 0.49 & 0.98 & 0.64 \\
\hline 8 & 01115276 & Westconnaug Brook (Westconnaug Reservoir) & 25 & 16 & 21 & 13 & 12 & 7.8 & 7.8 & 4.9 & 6.7 & 4.2 & 6.0 & 3.8 \\
\hline 9 & 01115275 & Bear Tree Brook & 10 & 6.2 & 8.8 & 5.2 & 5.1 & 3.0 & 3.3 & 2.0 & 2.6 & 1.6 & 2.7 & 1.6 \\
\hline 19 & 01115170 & $\begin{array}{l}\text { Moswansicut Reservoir (Moswansicut Stream } \\
\text { north, Moswansicut Pond) }\end{array}$ & 56 & 33 & 37 & 22 & 21 & 12 & 5.4 & 3.2 & 4.4 & 2.6 & 3.7 & 2.2 \\
\hline 14 & 01115110 & Huntinghouse Brook & 22 & 14 & 12 & 7.4 & 4.4 & 2.7 & 0.96 & 0.58 & 2.8 & 1.7 & 0.84 & 0.51 \\
\hline 15 & 01115114 & Regulating Reservoir (Rush Brook) & 53 & 33 & 28 & 17 & 17 & 10 & 4.5 & 2.7 & 5.2 & 3.1 & 1.9 & 1.1 \\
\hline 16 & 01115098 & Peeptoad Brook (Harrisdale Brook) & 56 & 33 & 36 & 21 & 17 & 9.8 & 6.0 & 3.5 & 9.9 & 5.8 & 3.0 & 1.7 \\
\hline 18 & 01115120 & $\begin{array}{l}\text { Unnamed tributary to Regulating Reservoir } \\
\text { (unnamed brook A) }\end{array}$ & 9.1 & 5.2 & 2.6 & 1.5 & 0.55 & 0.31 & 0.029 & 0.017 & 0.099 & 0.057 & 0.011 & 0.0064 \\
\hline- & - & Total & 450 & 270 & 280 & 170 & 140 & 83 & 47 & 28 & 58 & 35 & 32 & 19 \\
\hline
\end{tabular}

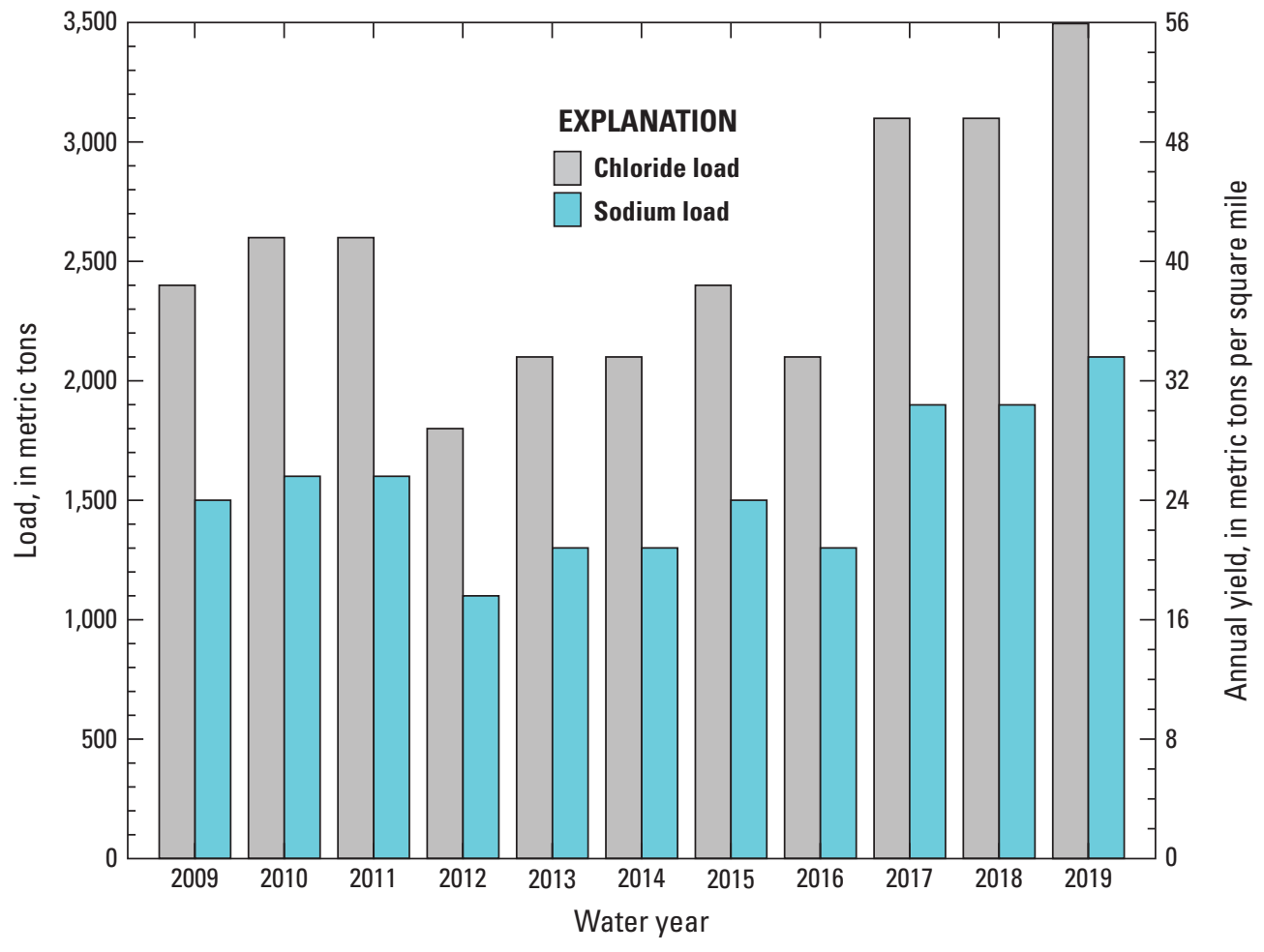

Figure 5. Annual loads and annual yields of chloride and sodium estimated from continuous measurements of flow and specific conductance for water years 2009-19 for the area upstream from 14 Providence Water Supply Board sampling stations in the Scituate Reservoir drainage area, Rhode Island. Locations of continuous water-quality monitoring stations shown on figure 1. 
Table 8. Median values for water-quality data collected at Providence Water Supply Board stations in the Scituate Reservoir drainage area, Rhode Island, from October 1, 2018, through September 30, 2019.

[Water-quality data are from samples collected and analyzed by the Providence Water Supply Board (PWSB). Alternate station names are listed in parentheses for stations where different historical names were used for the same sampling location by the PWSB. Locations of stations are shown on figure 1. USGS, U.S. Geological Survey; PCU, platinum cobalt unit; NTU, nephelometric turbidity unit; CFU/100 mL, colony forming unit per 100 milliliters; E. coli, Escherichia coli; mg/L, milligram per liter; $\mathrm{CaCO}_{3}$, calcium carbonate; $\mathrm{N}$, nitrogen; $\mathrm{PO}_{4}$, phosphate; <, less than; - , no data]

\begin{tabular}{|c|c|c|c|c|c|c|c|c|c|c|c|c|}
\hline \multirow[b]{2}{*}{$\begin{array}{l}\text { PWSB } \\
\text { station } \\
\text { number }\end{array}$} & \multirow[b]{2}{*}{$\begin{array}{l}\text { USGS } \\
\text { station } \\
\text { number }\end{array}$} & \multirow[b]{2}{*}{ Station name } & \multicolumn{3}{|c|}{ Properties } & \multicolumn{7}{|c|}{ Constituents } \\
\hline & & & $\mathrm{pH}$ & $\begin{array}{l}\text { Color } \\
\text { (PCU) }\end{array}$ & $\begin{array}{l}\text { Turbidity } \\
\text { (NTU) }\end{array}$ & $\begin{array}{l}\text { Total coliform } \\
\text { bacteria } \\
\text { (CFU/100 mL) }\end{array}$ & $\begin{array}{c}\text { E. coli } \\
\text { (CFU/100 } \\
\mathrm{mL})\end{array}$ & $\begin{array}{c}\text { Alkalinity } \\
\text { (mg/L as } \\
\mathrm{CaCO}_{3} \text { ) }\end{array}$ & $\begin{array}{l}\text { Chloride } \\
\text { (mg/L) }\end{array}$ & $\begin{array}{l}\text { Nitrite } \\
\text { (mg/L as } \\
\mathrm{N})\end{array}$ & $\begin{array}{c}\text { Nitrate } \\
\text { (mg/L as N) }\end{array}$ & $\begin{array}{l}\text { Orthophosphate } \\
\left(\mathrm{mg} / \mathrm{L} \text { as } \mathrm{PO}_{4}\right)\end{array}$ \\
\hline \multicolumn{13}{|c|}{ Barden Reservoir subbasin } \\
\hline 24 & 01115190 & Dolly Cole Brook & 6.4 & 62 & 0.57 & 1,400 & 10 & 4.7 & 26.0 & 0.001 & 0.07 & 0.03 \\
\hline 25 & 01115200 & Shippee Brook & 6.1 & 73 & 0.59 & 1,300 & 60 & 3.9 & 13.1 & 0.002 & $<0.05$ & 0.04 \\
\hline 26 & 01115185 & Windsor Brook & 6.2 & 63 & 0.39 & 830 & $<10$ & 3.9 & 26.0 & 0.001 & $<0.05$ & 0.03 \\
\hline 27 & 011151845 & $\begin{array}{l}\text { Unnamed tributary to } \\
\text { Ponaganset River (un- } \\
\text { named brook B, unnamed } \\
\text { brook west of Windsor } \\
\text { Brook) }\end{array}$ & 6.1 & 24 & 0.19 & 1,100 & 10 & 4.1 & 16.1 & 0.001 & $<0.05$ & 0.02 \\
\hline 28 & 01115265 & $\begin{array}{l}\text { Barden Reservoir (Hemlock } \\
\text { Brook) }\end{array}$ & 6.1 & 100 & 0.60 & 1,100 & 20 & 3.8 & 25.1 & 0.002 & 0.08 & 0.05 \\
\hline 29 & 01115271 & $\begin{array}{l}\text { Ponaganset River (Barden } \\
\text { Stream) }\end{array}$ & 6.3 & 50 & 0.59 & 410 & $<10$ & 4.2 & 22.1 & 0.001 & $<0.05$ & 0.03 \\
\hline 35 & 01115187 & Ponaganset River & 6.4 & 51 & 0.66 & 1,400 & 10 & 4.2 & 22.9 & 0.002 & 0.07 & 0.03 \\
\hline \multicolumn{13}{|c|}{ Direct runoff subbasin } \\
\hline 1 & 01115180 & Brandy Brook & 6.9 & 78 & 1.5 & 1,300 & 20 & 10 & 15.0 & 0.003 & 0.20 & 0.05 \\
\hline 2 & 01115181 & $\begin{array}{l}\text { Unnamed tributary \#2 to } \\
\text { Scituate Reservoir (un- } \\
\text { named brook north of } \\
\text { Bullhead Brook) }\end{array}$ & 6.3 & 20 & 0.33 & 1,900 & 74 & 6.0 & 75.3 & 0.001 & 0.15 & 0.02 \\
\hline 3 & 01115280 & Cork Brook & 6.5 & 37 & 0.32 & 910 & 10 & 5.2 & 40.1 & 0.001 & 0.19 & 0.04 \\
\hline 4 & 01115400 & $\begin{array}{l}\text { Kent Brook (Betty Pond } \\
\text { Stream) }\end{array}$ & 6.2 & 28 & 0.51 & 1,100 & $<10$ & 6.7 & 7.20 & 0.001 & $<0.05$ & 0.01 \\
\hline 5 & 01115184 & Spruce Brook & 6.3 & 54 & 0.63 & 2,100 & 21 & 4.8 & 19.9 & 0.002 & 0.28 & 0.03 \\
\hline 6 & 01115183 & Quonapaug Brook & 6.6 & 100 & 0.59 & 1,100 & 20 & 10 & 31.7 & 0.003 & 0.19 & 0.05 \\
\hline 7 & 01115297 & Wilbur Hollow Brook & 6.3 & 60 & 0.51 & 1,100 & 31 & 5.9 & 11.1 & 0.002 & $<0.05$ & 0.03 \\
\hline 8 & 01115276 & $\begin{array}{l}\text { Westconnaug Brook } \\
\text { (Westconnaug Reservoir) }\end{array}$ & 6.3 & 20 & 0.49 & 220 & $<10$ & 3.7 & 13.6 & 0.001 & $<0.05$ & 0.02 \\
\hline 9 & 01115275 & Bear Tree Brook & 6.4 & 59 & 0.93 & 2,600 & 36 & 6.3 & 51.1 & 0.002 & 0.49 & 0.04 \\
\hline
\end{tabular}


Table 8. Median values for water-quality data collected at Providence Water Supply Board stations in the Scituate Reservoir drainage area, Rhode Island, from October 1, 2018, through September 30, 2019.-Continued

[Water-quality data are from samples collected and analyzed by the Providence Water Supply Board (PWSB). Alternate station names are listed in parentheses for stations where different historical names were used for the same sampling location by the PWSB. Locations of stations are shown on figure 1. USGS, U.S. Geological Survey; PCU, platinum cobalt unit; NTU, nephelometric turbidity unit; CFU/100 mL, colony forming unit per 100 milliliters; E. coli, Escherichia coli; $\mathrm{mg} / \mathrm{L}$, milligram per liter; $\mathrm{CaCO}_{3}$, calcium carbonate; $\mathrm{N}$, nitrogen; $\mathrm{PO}_{4}$, phosphate; <, less than; —, no data]

\begin{tabular}{|c|c|c|c|c|c|c|c|c|c|c|c|c|}
\hline \multirow[b]{2}{*}{$\begin{array}{l}\text { PWSB } \\
\text { station } \\
\text { number }\end{array}$} & \multirow[b]{2}{*}{$\begin{array}{l}\text { USGS } \\
\text { station } \\
\text { number }\end{array}$} & \multirow[b]{2}{*}{ Station name } & \multicolumn{3}{|c|}{ Properties } & \multicolumn{7}{|c|}{ Constituents } \\
\hline & & & $\mathrm{pH}$ & $\begin{array}{l}\text { Color } \\
\text { (PCU) }\end{array}$ & $\begin{array}{c}\text { Turbidity } \\
\text { (NTU) }\end{array}$ & $\begin{array}{l}\text { Total coliform } \\
\text { bacteria } \\
\text { (CFU/100 mL) }\end{array}$ & $\begin{array}{c}\text { E. coli } \\
\text { (CFU/100 } \\
\mathrm{mL})\end{array}$ & $\begin{array}{c}\text { Alkalinity } \\
\text { (mg/L as } \\
\mathrm{CaCO}_{3} \text { ) }\end{array}$ & $\begin{array}{c}\text { Chloride } \\
\text { (mg/L) }\end{array}$ & $\begin{array}{l}\text { Nitrite } \\
\text { (mg/L as } \\
\mathrm{N} \text { ) }\end{array}$ & $\begin{array}{c}\text { Nitrate } \\
\text { (mg/L as N) }\end{array}$ & $\begin{array}{c}\text { Orthophosphate } \\
\left(\mathrm{mg} / \mathrm{L} \text { as } \mathrm{PO}_{4}\right)\end{array}$ \\
\hline \multicolumn{13}{|c|}{ Direct runoff subbasin-Continued } \\
\hline 30 & 01115350 & $\begin{array}{l}\text { Unnamed tributary \#4 } \\
\text { to Scituate Reservoir } \\
\text { (Coventry Brook, Knight } \\
\text { Brook) }\end{array}$ & 6.0 & 73 & 0.78 & 2,800 & 10 & 4.2 & 33.7 & 0.001 & 0.10 & 0.06 \\
\hline 31 & 01115177 & Toad Pond & 6.5 & 40 & 0.60 & 130 & $<10$ & 20 & 170 & 0.003 & 0.81 & 0.04 \\
\hline 32 & 01115178 & $\begin{array}{l}\text { Unnamed tributary \#1 to } \\
\text { Scituate Reservoir (Pine } \\
\text { Swamp Brook) }\end{array}$ & 6.6 & 100 & 0.92 & 960 & $<10$ & 9.5 & 13.5 & 0.002 & 0.26 & 0.07 \\
\hline 33 & 01115182 & $\begin{array}{l}\text { Unnamed tributary \#3 to } \\
\text { Scituate Reservoir (Hall's } \\
\text { Estate Brook) }\end{array}$ & 6.2 & 38 & 0.31 & 740 & 20 & 5.5 & 13.1 & 0.001 & 0.19 & 0.05 \\
\hline 36 & - & Outflow from King Pond & 6.6 & 37 & 0.28 & 1,000 & 25 & 4.9 & 7.80 & 0.001 & 0.06 & 0.03 \\
\hline 37 & - & Fire Tower Stream & 5.9 & 28 & 0.17 & 900 & $<10$ & 3.6 & 8.45 & $<0.001$ & $<0.05$ & 0.02 \\
\hline \multicolumn{13}{|c|}{ Moswansicut Reservoir subbasin } \\
\hline 19 & 01115170 & $\begin{array}{l}\text { Moswansicut Reservoir } \\
\text { (Moswansicut Stream } \\
\text { north, Moswansicut } \\
\text { Pond) }\end{array}$ & 7.0 & 20 & 0.6 & 81 & $<10$ & 9.6 & 59.1 & 0.001 & 0.12 & 0.02 \\
\hline 20 & 01115160 & $\begin{array}{l}\text { Unnamed tributary \#1 to } \\
\text { Moswansicut Reservoir } \\
\text { (Blanchard Brook) }\end{array}$ & 6.4 & 180 & 0.54 & 530 & 10 & 7.1 & 70.6 & 0.003 & 0.22 & 0.11 \\
\hline 21 & 01115165 & $\begin{array}{l}\text { Unnamed tributary \#2 to } \\
\text { Moswansicut Reservoir } \\
\text { (Brook from Kimball } \\
\text { Reservoir) }\end{array}$ & 6.5 & 43 & 1.10 & 7,500 & 15 & 15 & 44.8 & 0.004 & 0.40 & 0.06 \\
\hline 22 & 01115167 & $\begin{array}{l}\text { Moswansicut Reservoir } \\
\text { (Moswansicut Stream } \\
\text { south) }\end{array}$ & 6.7 & 25 & 1.10 & 1,500 & 36 & 14 & 55.1 & 0.004 & 0.85 & 0.04 \\
\hline 34 & 01115164 & Kimball Stream & 6.5 & 65 & 0.95 & 540 & $<10$ & 11 & 37.8 & 0.003 & 0.17 & 0.06 \\
\hline
\end{tabular}


Table 8. Median values for water-quality data collected at Providence Water Supply Board stations in the Scituate Reservoir drainage area, Rhode Island, from October 1, 2018, through September 30, 2019.-Continued

[Water-quality data are from samples collected and analyzed by the Providence Water Supply Board (PWSB). Alternate station names are listed in parentheses for stations where different historical names were used for the same sampling location by the PWSB. Locations of stations are shown on figure 1. USGS, U.S. Geological Survey; PCU, platinum cobalt unit; NTU, nephelometric turbidity unit; CFU/100 mL, colony forming unit per 100 milliliters; E. coli, Escherichia coli; $\mathrm{mg} / \mathrm{L}$, milligram per liter; $\mathrm{CaCO}_{3}$, calcium carbonate; $\mathrm{N}$, nitrogen; $\mathrm{PO}_{4}$, phosphate; <, less than; - , no data]

\begin{tabular}{|c|c|c|c|c|c|c|c|c|c|c|c|c|}
\hline \multirow[b]{2}{*}{$\begin{array}{l}\text { PWSB } \\
\text { station } \\
\text { number }\end{array}$} & \multirow{2}{*}{$\begin{array}{l}\text { USGS } \\
\text { station } \\
\text { number }\end{array}$} & \multirow[b]{2}{*}{ Station name } & \multicolumn{3}{|c|}{ Properties } & \multicolumn{7}{|c|}{ Constituents } \\
\hline & & & $\mathrm{pH}$ & $\begin{array}{l}\text { Color } \\
\text { (PCU) }\end{array}$ & $\begin{array}{c}\text { Turbidity } \\
\text { (NTU) }\end{array}$ & $\begin{array}{c}\text { Total coliform } \\
\text { bacteria } \\
\text { (CFU/100 mL) } \\
\end{array}$ & $\begin{array}{c}\text { E. coli } \\
\text { (CFU/100 } \\
\mathrm{mL})\end{array}$ & $\begin{array}{c}\text { Alkalinity } \\
\text { (mg/L as } \\
\left.\mathrm{CaCO}_{3}\right)\end{array}$ & $\begin{array}{c}\text { Chloride } \\
\text { (mg/L) }\end{array}$ & $\begin{array}{l}\text { Nitrite } \\
\text { (mg/L as } \\
\mathrm{N})\end{array}$ & $\begin{array}{c}\text { Nitrate } \\
\text { (mg/L as N) }\end{array}$ & $\begin{array}{l}\text { Orthophosphate } \\
\left(\mathrm{mg} / \mathrm{L} \text { as } \mathrm{PO}_{4}\right)\end{array}$ \\
\hline \multicolumn{13}{|c|}{ Ponaganset Reservoir subbasin } \\
\hline 23 & 011151843 & Ponaganset Reservoir & 6.2 & 18 & 0.62 & 280 & $<10$ & 3.2 & 19.5 & 0.001 & $<0.05$ & 0.03 \\
\hline \multicolumn{13}{|c|}{ Regulating Reservoir subbasin } \\
\hline 13 & 01115176 & Regulating Reservoir & 6.7 & 35 & 0.82 & 260 & $<10$ & 8.7 & 43 & 0.001 & $<0.05$ & 0.02 \\
\hline 14 & 01115110 & Huntinghouse Brook & 6.6 & 41 & 0.56 & 880 & 31 & 7.1 & 15.2 & 0.001 & 0.11 & 0.03 \\
\hline 15 & 01115114 & Rush Brook & 6.8 & 58 & 0.67 & 770 & 26 & 9.7 & 53.9 & 0.001 & 0.11 & 0.04 \\
\hline 16 & 01115098 & $\begin{array}{l}\text { Peeptoad Brook (Harrisdale } \\
\text { Brook) }\end{array}$ & 6.6 & 40 & 0.82 & 720 & 10 & 10 & 44.6 & 0.001 & 0.08 & 0.03 \\
\hline 17 & 01115119 & Dexter Pond (Paine Pond) & 6.1 & 85 & 0.74 & 1,700 & 48 & 8.7 & 38.7 & 0.002 & $<0.05$ & 0.03 \\
\hline 18 & 01115120 & $\begin{array}{l}\text { Unnamed tributary to } \\
\text { Regulating Reservoir } \\
\text { (unnamed brook A) }\end{array}$ & 6.4 & 90 & 1.0 & 2,400 & 88 & 10 & 66.6 & 0.004 & 0.25 & 0.07 \\
\hline \multicolumn{13}{|c|}{ Westconnaug Reservoir subbasin } \\
\hline 10 & 01115274 & Westconnaug Brook & 5.8 & 30 & 0.31 & 1,600 & 10 & 3.1 & 23.9 & 0.001 & $<0.05$ & 0.03 \\
\hline 11 & 01115273 & $\begin{array}{l}\text { Unnamed tributary to } \\
\text { Westconnaug Reservoir } \\
\text { (unnamed brook south of } \\
\text { Westconnaug Reservoir) }\end{array}$ & 5.8 & 80 & 0.53 & 890 & 10 & 4.0 & 8.20 & 0.002 & $<0.05$ & 0.04 \\
\hline 12 & 011152745 & $\begin{array}{l}\text { Unnamed tributary to } \\
\text { Westconnaug Brook } \\
\text { (unnamed brook north of } \\
\text { Westconnaug reservoir) }\end{array}$ & 6.2 & 25 & 0.47 & 510 & $<10$ & 4.8 & 17.1 & 0.001 & $<0.05$ & 0.03 \\
\hline \multicolumn{13}{|c|}{ Scituate Reservoir drainage area } \\
\hline - & - & Minimum & 5.8 & 18 & 0.17 & 81 & $<10$ & 3.1 & 7.2 & $<0.001$ & $<0.05$ & 0.01 \\
\hline & & Median & 6.4 & 50 & 0.59 & 1,000 & 10 & 5.9 & 25.1 & 0.001 & 0.08 & 0.03 \\
\hline & & Maximum & 7.0 & 180 & 1.5 & 7,500 & 88 & 20 & 170 & 0.004 & 0.85 & 0.11 \\
\hline
\end{tabular}


Table 9. Median daily loads of bacteria, chloride, nitrite, nitrate, and orthophosphate in the Scituate Reservoir drainage area, Rhode Island, from October 1, 2018, through September 30, 2019.

[Water-quality data are from samples collected and analyzed by the Providence Water Supply Board (PWSB). Alternate station names are listed in parentheses for stations where different historical names were used for the same sampling location by the PWSB. Locations of stations are shown on figure 1. USGS, U.S. Geological Survey; CFU $\times 10^{6} / \mathrm{d}$; millions of colony forming units per day; E. coli, Escherichia coli; kg/d, kilogram per day; g/d, grams per day; N, nitrogen;

$\mathrm{PO}_{4}$, phosphate; - , not applicable]

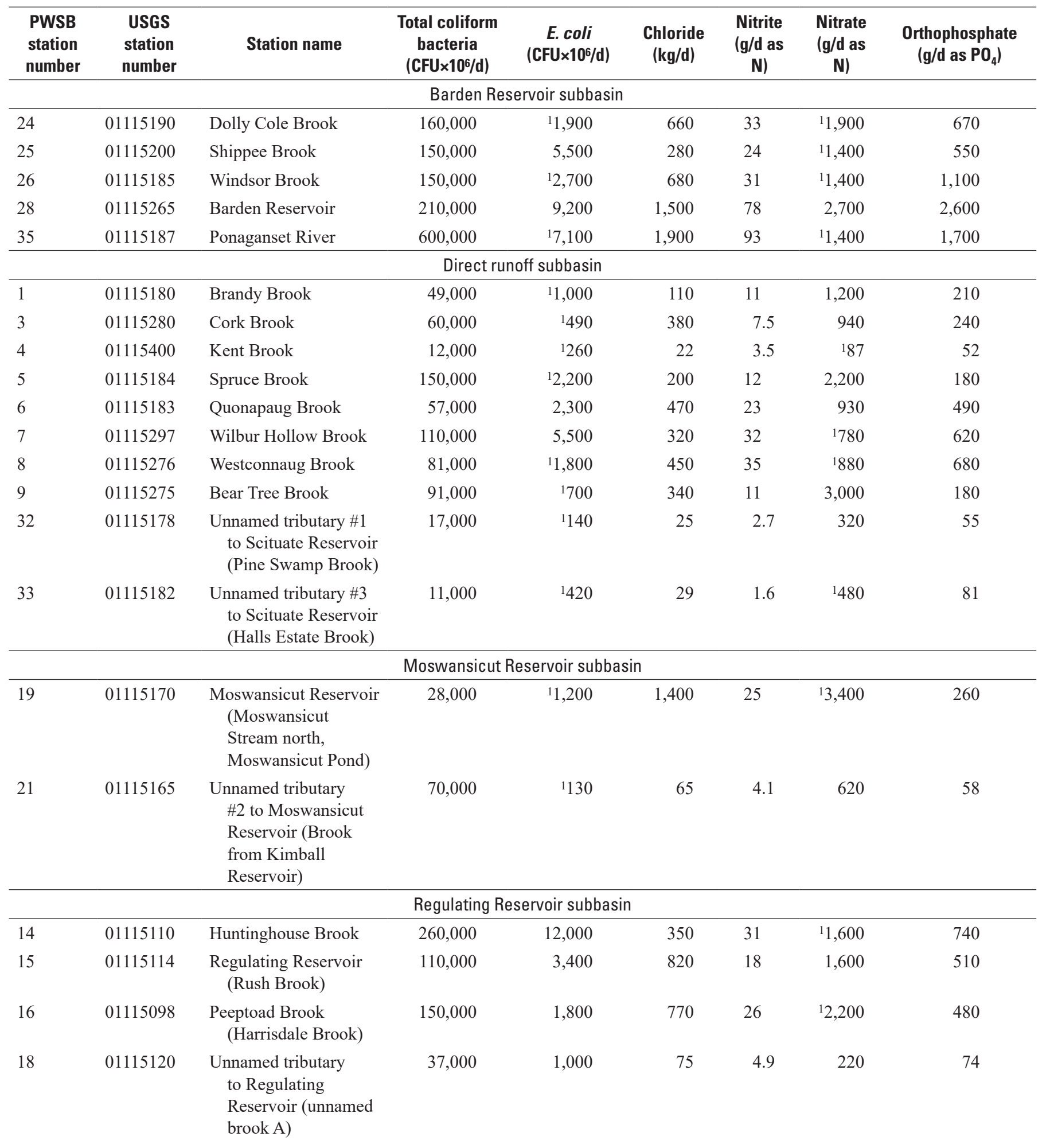


Table 9. Median daily loads of bacteria, chloride, nitrite, nitrate, and orthophosphate in the Scituate Reservoir drainage area, Rhode Island, from October 1, 2018, through September 30, 2019.-Continued

[Water-quality data are from samples collected and analyzed by the Providence Water Supply Board (PWSB). Alternate station names are listed in parentheses for stations where different historical names were used for the same sampling location by the PWSB. Locations of stations are shown on figure 1. USGS, U.S. Geological Survey; $\mathrm{CFU} \times 10^{6} / \mathrm{d}$; millions of colony forming units per day; E. coli, Escherichia coli; kg/d, kilogram per day; g/d, grams per day; N, nitrogen; $\mathrm{PO}_{4}$, phosphate; - , not applicable]

\begin{tabular}{|c|c|c|c|c|c|c|c|c|}
\hline $\begin{array}{l}\text { PWSB } \\
\text { station } \\
\text { number }\end{array}$ & $\begin{array}{l}\text { USGS sta- } \\
\text { tion number }\end{array}$ & Station name & $\begin{array}{l}\text { Total coliform } \\
\text { bacteria } \\
\text { (CFU×106/d) }\end{array}$ & $\begin{array}{c}\text { E. Coli } \\
\left.\text { (CFU } \times 10^{6} / d\right)\end{array}$ & $\begin{array}{c}\text { Chloride } \\
\text { (kg/d) }\end{array}$ & $\begin{array}{l}\text { Nitrite } \\
\text { (g/d as } \\
\text { N) }\end{array}$ & $\begin{array}{l}\text { Nitrate } \\
(\mathrm{g} / \mathrm{d} \text { as } \\
\mathrm{N})\end{array}$ & $\begin{array}{l}\text { Orthophosphate } \\
\left(\mathrm{g} / \mathrm{d} \text { as } \mathrm{PO}_{4}\right)\end{array}$ \\
\hline \multicolumn{9}{|c|}{ Westconnaug Reservoir subbasin } \\
\hline 10 & 01115274 & Westconnaug Brook & 40,000 & 1500 & 200 & 8.3 & 1220 & 210 \\
\hline 11 & 01115273 & $\begin{array}{l}\text { Unnamed tributary } \\
\text { to Westconnaug } \\
\text { Reservoir (un- } \\
\text { named brook south } \\
\text { of Westconnaug } \\
\text { Reservoir) }\end{array}$ & 20,000 & 1940 & 41 & 6.5 & ${ }^{1} 120$ & 410 \\
\hline \multicolumn{9}{|c|}{ Scituate Reservoir drainage area } \\
\hline \multirow[t]{3}{*}{-} & - & Minimum & 11,000 & 1130 & 22 & 1.6 & 187 & 52 \\
\hline & & Median & 81,000 & ${ }^{1} 1,800$ & 340 & 18 & 1,000 & 410 \\
\hline & & Maximum & 600,000 & 12,000 & 1,900 & 93 & 3,000 & 2,600 \\
\hline
\end{tabular}

${ }^{1}$ The concentrations used to calculate the loads were censored as one-half the method detection limit. 
Table 10. Median daily yields of bacteria, chloride, nitrite, nitrate, and orthophosphate in the Scituate Reservoir drainage area, Rhode Island, from October 1, 2018, through September 30, 2019.

[Water-quality data are from samples collected and analyzed by Providence Water Supply Board (PWSB). Locations of stations shown on figure 1. USGS, U.S. Geological Survey; CFU $\times 10^{6} / \mathrm{d} / \mathrm{mi}^{2}$; millions of colony forming units per day per square mile; E. coli, Escherichia coli; $\mathrm{N}$, nitrogen; $\mathrm{PO}_{4}, \mathrm{phosphate}^{\mathrm{k}} \mathrm{kg} / \mathrm{d} / \mathrm{mi}^{2}$, kilogram per day per square mile; $\mathrm{g} / \mathrm{d} / \mathrm{mi}^{2}$, gram per day per square mile; —, none]

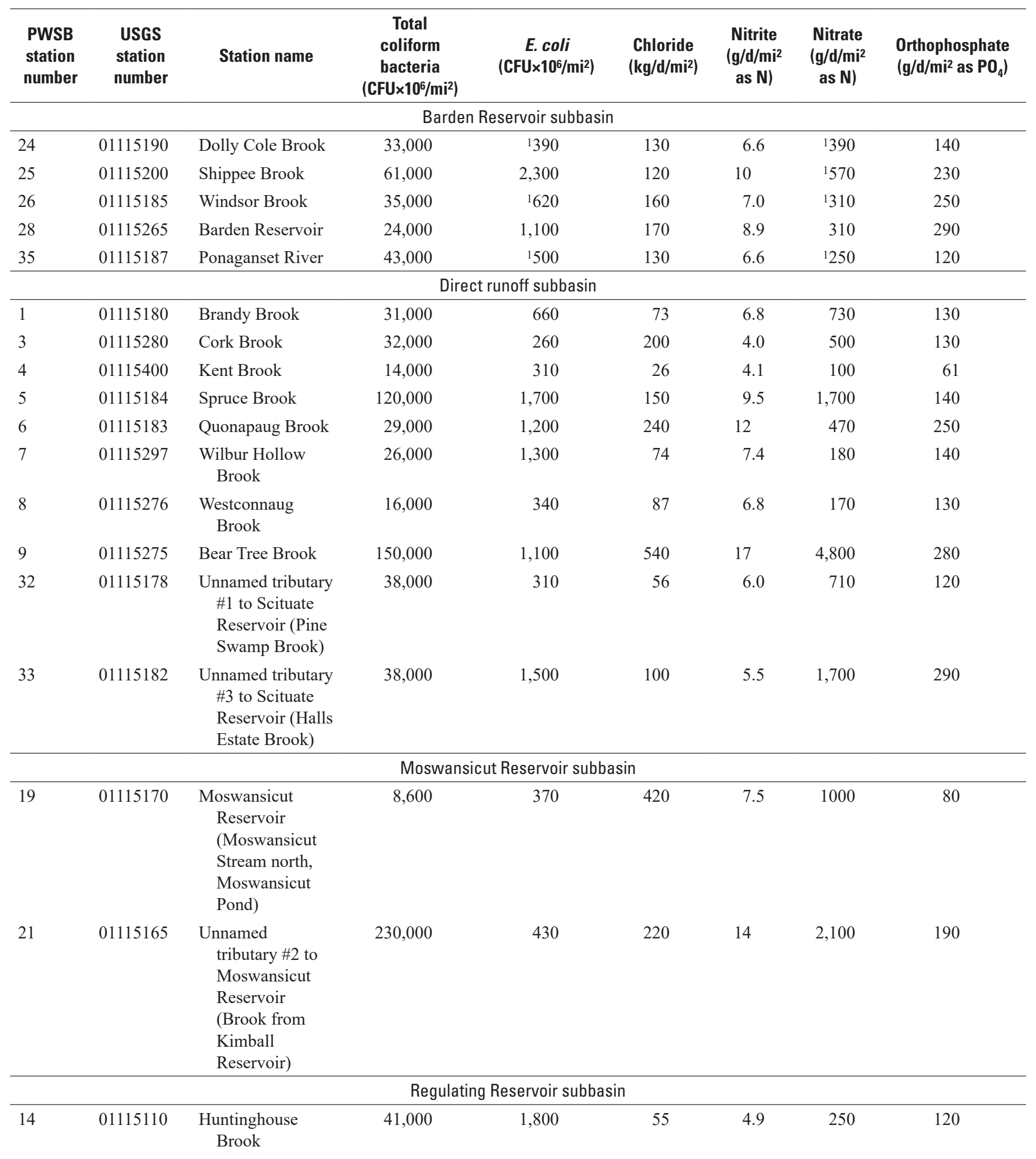


Table 10. Median daily yields of bacteria, chloride, nitrite, nitrate, and orthophosphate in the Scituate Reservoir drainage area, Rhode Island, from October 1, 2018, through September 30, 2019.-Continued

[Water-quality data are from samples collected and analyzed by Providence Water Supply Board (PWSB). Locations of stations shown on figure 1. USGS, U.S. Geological Survey; $\mathrm{CFU} \times 10^{6} / \mathrm{d} / \mathrm{mi}^{2}$; millions of colony forming units per day per square mile; E. coli, Escherichia coli; $\mathrm{N}$, nitrogen; $\mathrm{PO}_{4}$, phosphate; $\mathrm{kg} / \mathrm{d} / \mathrm{mi}^{2}$, kilogram per day per square mile; $\mathrm{g} / \mathrm{d} / \mathrm{mi}^{2}$, gram per day per square mile; —, none]

\begin{tabular}{|c|c|c|c|c|c|c|c|c|}
\hline $\begin{array}{l}\text { PWSB } \\
\text { station } \\
\text { number }\end{array}$ & $\begin{array}{l}\text { USGS } \\
\text { station } \\
\text { number }\end{array}$ & Station name & $\begin{array}{c}\text { Total } \\
\text { coliform } \\
\text { bacteria } \\
\left(\mathrm{CFU} \times 10^{6} / \mathrm{mi}^{2}\right)\end{array}$ & $\begin{array}{c}\text { E. coli } \\
\left(\text { CFU } \times 10^{6} / \mathrm{mi}^{2}\right)\end{array}$ & $\begin{array}{l}\text { Chloride } \\
\left(\mathrm{kg} / \mathrm{d} / \mathrm{mi}^{2}\right)\end{array}$ & $\begin{array}{l}\text { Nitrite } \\
\left(\mathrm{g} / \mathrm{d} / \mathrm{mi}^{2}\right. \\
\text { as } \mathrm{N})\end{array}$ & $\begin{array}{l}\text { Nitrate } \\
\left(\mathrm{g} / \mathrm{d} / \mathrm{mi}^{2}\right. \\
\text { as } \mathrm{N})\end{array}$ & $\begin{array}{l}\text { Orthophosphate } \\
\left(\mathrm{g} / \mathrm{d} / \mathrm{mi}^{2} \text { as } \mathrm{PO}_{4}\right)\end{array}$ \\
\hline \multicolumn{9}{|c|}{ Regulating Reservoir subbasin-Continued } \\
\hline 15 & 01115114 & $\begin{array}{l}\text { Regulating } \\
\text { Reservoir (Rush } \\
\text { Brook) }\end{array}$ & 22,000 & 710 & 170 & 3.7 & 340 & 110 \\
\hline 16 & 01115098 & $\begin{array}{l}\text { Peeptoad Brook } \\
\text { (Harrisdale } \\
\text { Brook) }\end{array}$ & 30,000 & 360 & 150 & 5.2 & 440 & 96 \\
\hline 18 & 01115120 & $\begin{array}{l}\text { Unnamed tributary } \\
\text { to Regulating } \\
\text { Reservoir (un- } \\
\text { named brook A) }\end{array}$ & 130,000 & 3,700 & 270 & 17 & 790 & 260 \\
\hline 11 & 01115273 & $\begin{array}{l}\text { Unnamed tributary } \\
\text { to Westconnaug } \\
\text { Reservoir } \\
\text { (unnamed } \\
\text { brook south of } \\
\text { Westconnaug } \\
\text { Reservoir) }\end{array}$ & 28,000 & 1,300 & 56 & 9.0 & 170 & 560 \\
\hline \multicolumn{9}{|c|}{ Scituate Reservoir drainage area } \\
\hline- & - & Minimum & 8,600 & 260 & 26 & 3.70 & 100 & 61 \\
\hline
\end{tabular}

${ }^{1}$ The concentrations used to calculate the yields were censored as one-half the method detection limit. 


\section{References Cited}

Baird, R.B., Eaton, A.D., and Rice, E.W., eds., 2018, Standard methods for the examination of water and wastewater $(23 \mathrm{~d}$ ed.): American Public Health Association, American Water Works Association, and Water Environment Federation, [variously paged], accessed October 4, 2018, at https:// www.standardmethods.org/.

Best, J., Cockerel, B.L., Jr., Dichter, G., and Hall, N.H., northeimer, W.W., Reynolds, V., and Solo-Gabriele, H., 2018, 9223-Enzyme substrate coliform test, in Baird, R.B., Eaton, A.D., and Rice, E.W., eds., Standard methods for the examination of water and wastewater ( $23 \mathrm{~d}$ ed.): American Public Health Association, American Water Works Association, and Water Environment Federation, 4 p., accessed October 4, 2018, at https://www.standardme thods.org/doi/10.2105/SMWW.2882.194.

Breault, R.F., 2010, Streamflow, water quality, and constituent loads and yields, Scituate Reservoir drainage area, Rhode Island, water year 2002: U.S. Geological Survey Open-File Report 2009-1041, 25 p. [Also available at https://doi.org/10.3133/ofr20091041.]

Breault, R.F., and Campbell, J.P., 2010a, Streamflow, water quality, and constituent loads and yields, Scituate Reservoir drainage area, Rhode Island, water year 2003: U.S. Geological Survey Open-File Report 2010-1043, 24 p. [Also available at https://doi.org/10.3133/ofr20101043.]

Breault, R.F., and Campbell, J.P., 2010b, Streamflow, water quality, and constituent loads and yields, Scituate Reservoir drainage area, Rhode Island, water year 2004: U.S. Geological Survey Open-File Report 2010-1044, 24 p. [Also available at https://doi.org/10.3133/ofr20101044.]

Breault, R.F., and Campbell, J.P., 2010c, Streamflow, water quality, and constituent loads and yields, Scituate Reservoir drainage area, Rhode Island, water year 2005: U.S. Geological Survey Open-File Report 2010-1045, 24 p. [Also available at https://doi.org/10.3133/ofr20101045.]

Breault, R.F., and Campbell, J.P., 2010d, Streamflow, water quality, and constituent loads and yields, Scituate Reservoir drainage area, Rhode Island, water year 2006: U.S. Geological Survey Open-File Report 2010-1046, 25 p. [Also available at https://doi.org/10.3133/ofr20101046.]

Breault, R.F., and Smith, K.P., 2010, Streamflow, water quality, and constituent loads and yields, Scituate Reservoir drainage area, Rhode Island, water year 2009: U.S. Geological Survey Open-File Report 2010-1275, 24 p. [Also available at https://doi.org/10.3133/ofr20101275.]
Breault, R.F., Sorenson, J.R., and Weiskel, P.K., 2002, Streamflow, water quality, and contaminant loads in the lower Charles River watershed, Massachusetts, 1999-2000: U.S. Geological Survey Water-Resources Investigations Report 2002-4137, 131 p. [Also available at https://doi.org/10.3133/wri024137.]

Breault, R.F., Waldron, M.C., Barlow, L.K., and Dickerman, D.C., 2000, Water-quality conditions in relation to drainage basin characteristics in the Scituate Reservoir basin, Rhode Island, 1982-95: U.S. Geological Survey Water-Resources Investigations Report 2000-4086, 46 p. [Also available at https://doi.org/10.3133/wri004086.]

Hach Company, 2000, DR/2010 spectrophotometer procedures manual, rev. 2: Loveland, Colo., Hach Company, 657 p.

Helsel, D.R., and Hirsch, R.M., 2002, Statistical methods in water resources: U.S. Geological Survey Techniques of Water-Resources Investigations, book 4, chap. A3, 522 p. [Also available at https://doi.org/10.3133/twri04A3.]

Hirsch, R.M., 1982, A comparison of four streamflow record extension techniques: Water Resources Research, v. 18, no. 4, p. 1081-1088. [Also available at https://doi.org/10.1029/WR018i004p01081.]

Hirsch, R.M., and Gilroy, E.J., 1984, Methods of fitting a straight line to data-Examples in water resources: Water Resources Bulletin, v. 20, no. 5, p. 705-711. [Also available at https://doi.org/10.1111/j.1752-1688.1984.tb04753.x.]

Holm, T.R., Bennett, J., Blakesley, R., Gleichauf, G.K., Jagessar, P.K., Lipps, W.C., Vilissova, N., and Woodall, M.A., 2018, 4500- $\mathrm{NO}_{3}{ }^{-}$- Nitrogen (nitrate), in Baird, R.B., Eaton, A.D., and Rice, E.W., eds., Standard methods for the examination of water and wastewater ( $23 \mathrm{~d}$ ed.): American Public Health Association, American Water Works Association, and Water Environment Federation, 13 p., accessed October 4, 2018, at https://www.standardme thods.org/doi/10.2105/SMWW.2882.089.

Nimiroski, M.T., DeSimone, L.A., and Waldron, M.C., 2008, Water-quality conditions and constituent loads, 1996-2002, and water-quality trends, 1983-2002, in the Scituate Reservoir drainage area, Rhode Island: U.S. Geological Survey Scientific Investigations Report 2008-5060, 55 p. [Also available at https://doi.org/10.3133/sir20085060.]

Nimiroski, M.T., and Waldron, M.C., 2002, Sources of sodium and chloride in the Scituate Reservoir drainage basin, Rhode Island: U.S. Geological Survey Water-Resources Investigations Report 2002-4149, 16 p. [Also available at https://doi.org/10.3133/wri024149.] 
Ries, K.G., III, and Friesz, P.J., 2000, Methods for estimating low-flow statistics for Massachusetts streams: U.S. Geological Survey Water-Resources Investigations Report 2000-4135, 81 p. [Also available at https://doi.org/10.3133/wri004135.]

Smith, K.P., 2013, Streamflow, water quality, and constituent loads and yields, Scituate Reservoir drainage area, Rhode Island, water year 2011: U.S. Geological Survey Open-File Report 2013-1127, 32 p. [Also available at https://doi.org/10.3133/ofr20131127.]

Smith, K.P., 2014, Streamflow, water quality, and constituent loads and yields, Scituate Reservoir drainage area, Rhode Island, water year 2012: U.S. Geological Survey Open-File Report 2013-1274, 30 p. [Also available at https://doi.org/10.3133/ofr20131274.]

Smith, K.P., 2015a, Streamflow, water quality, and constituent loads and yields, Scituate Reservoir drainage area, Rhode Island, water year 2013: U.S. Geological Survey OpenFile Report 2015-1082, 31 p., accessed June 3, 2015, at https://doi.org/10.3133/ofr20151082.

Smith, K.P., 2015b, Water-quality trends in the Scituate reservoir drainage area, Rhode Island, 1983-2012: U.S. Geological Survey Scientific Investigations Report 2015-5058, 57 p. [Also available at https://doi.org/10.3133/sir20155058.]

Smith, K.P., 2016, Streamflow, water quality, and constituent loads and yields, Scituate Reservoir drainage area, Rhode Island, water year 2014: U.S. Geological Survey Open-File Report 2016-1051, 31 p. [Also available at https://doi.org/10.3133/ofr20161051.]

Smith, K.P., 2018a, Streamflow, water quality, and constituent loads and yields, Scituate Reservoir drainage area, Rhode Island, water year 2015: U.S. Geological Survey Open-File Report 2018-1065, 28 p. [Also available at https://doi.org/10.3133/ofr20181065.]

Smith, K.P., 2018b, Streamflow, water quality, and constituent loads and yields, Scituate Reservoir drainage area, Rhode Island, water year 2016: U.S. Geological Survey Open-File Report 2018-1065, 32 p. [Also available at https://doi.org/10.3133/ofr20181084.]

Smith, K.P., 2018c, Water quality data from the Providence Water Supply Board for tributary streams to the Scituate Reservoir, water year 2015: U.S. Geological Survey data release, https://doi.org/10.5066/F7FJ2FR5.

Smith, K.P., 2018d, Water quality data from the Providence Water Supply Board for tributary streams to the Scituate Reservoir, water year 2016: U.S. Geological Survey data release, https://doi.org/10.5066/F7Z60NC5.
Smith, K.P., 2019a, Streamflow, water quality, and constituent loads and yields, Scituate Reservoir drainage area, Rhode Island, water year 2017: U.S. Geological Survey Open-File Report 2018-1039, 33 p. [Also available at https://doi.org/10.3133/ofr20191039.]

Smith, K.P., 2019b, Water quality data from the Providence Water Supply Board for tributary streams to the Scituate Reservoir, water year 2017: U.S. Geological Survey data release, https://doi.org/10.5066/P9PPAKP6.

Smith, K.P., 2021a, Streamflow, water quality, and constituent loads and yields, Scituate Reservoir drainage area, Rhode Island, water year 2018: U.S. Geological Survey Data Report 1144, 36 p., https://doi.org/10.3133/dr1144.

Smith, K.P., 2021b, Water quality data from the Providence Water Supply Board for tributary streams to the Scituate Reservoir, water year 2018-19: U.S. Geological Survey data release, https://doi.org/10.5066/P9WK8N0F.

Smith, K.P., and Breault, R.F., 2011, Streamflow, water quality, and constituent loads and yields, Scituate Reservoir drainage area, Rhode Island, water year 2010: U.S. Geological Survey Open-File Report 2011-1076, 26 p. [Also available at https://doi.org/10.3133/ofr20111076.]

Tasker, G.D., and Driver, N.E., 1988, Nationwide regression models for predicting urban runoff water quality at unmonitored sites: Water Resources Bulletin, v. 24, no. 5, p. 1091-1101. [Also available at https://doi.org/10.1111/j.1752-1688.1988.tb03026.x.]

U.S. Environmental Protection Agency, 1993, Method 353.2, revision 2.0-Determination of nitrate-nitrite nitrogen by automated colorimetry: U.S. Environmental Protection Agency, [variously paged], accessed June 10, 2016, at https://www.epa.gov/sites/production/files/2015-8/ documents/method_353-2_1993.pdf.

U.S. Geological Survey, 2020, USGS water data for the nation: U.S. Geological Survey National Water Information System database, accessed May 28, 2020, at https://doi.org/ 10.5066/F7P55KJN.

Wagner, R.J., Boulger, R.W., Jr., Oblinger, C.J., and Smith, B.A., 2006, Guidelines and standard procedures for continuous water-quality monitors-Station operation, record computation, and data reporting: U.S. Geological Survey Techniques and Methods, book 1, chap. D3, 8 attachments, accessed April 10, 2006, at https://doi.org/10.3133/tm1D3. 
Table 4. Daily loads of bacteria, chloride, nitrite, nitrate, and orthophosphate in the Scituate Reservoir drainage area, Rhode Island, from 0ctober 1, 2018, through September 30, 2019.

[Water-quality data are from samples collected and analyzed by the Providence Water Supply Board (PWSB). Alternate station names are listed in parentheses for stations where different historical names were used for the same sampling location by the PWSB. Locations of stations shown on figure 1. USGS, U.S. Geological Survey; $\mathrm{ft}^{\mathrm{t}} \mathrm{s}$, cubic foot per second; CFU $\times 10^{6} / \mathrm{d}$; millions of colony forming units per day; E. coli, Escherichia coli; $\mathrm{kg} / \mathrm{d}$, kilogram per day; g/d, gram per day; N, nitrogen; $\mathrm{PO}_{4}$, phosphate; <, less than; >, greater than]

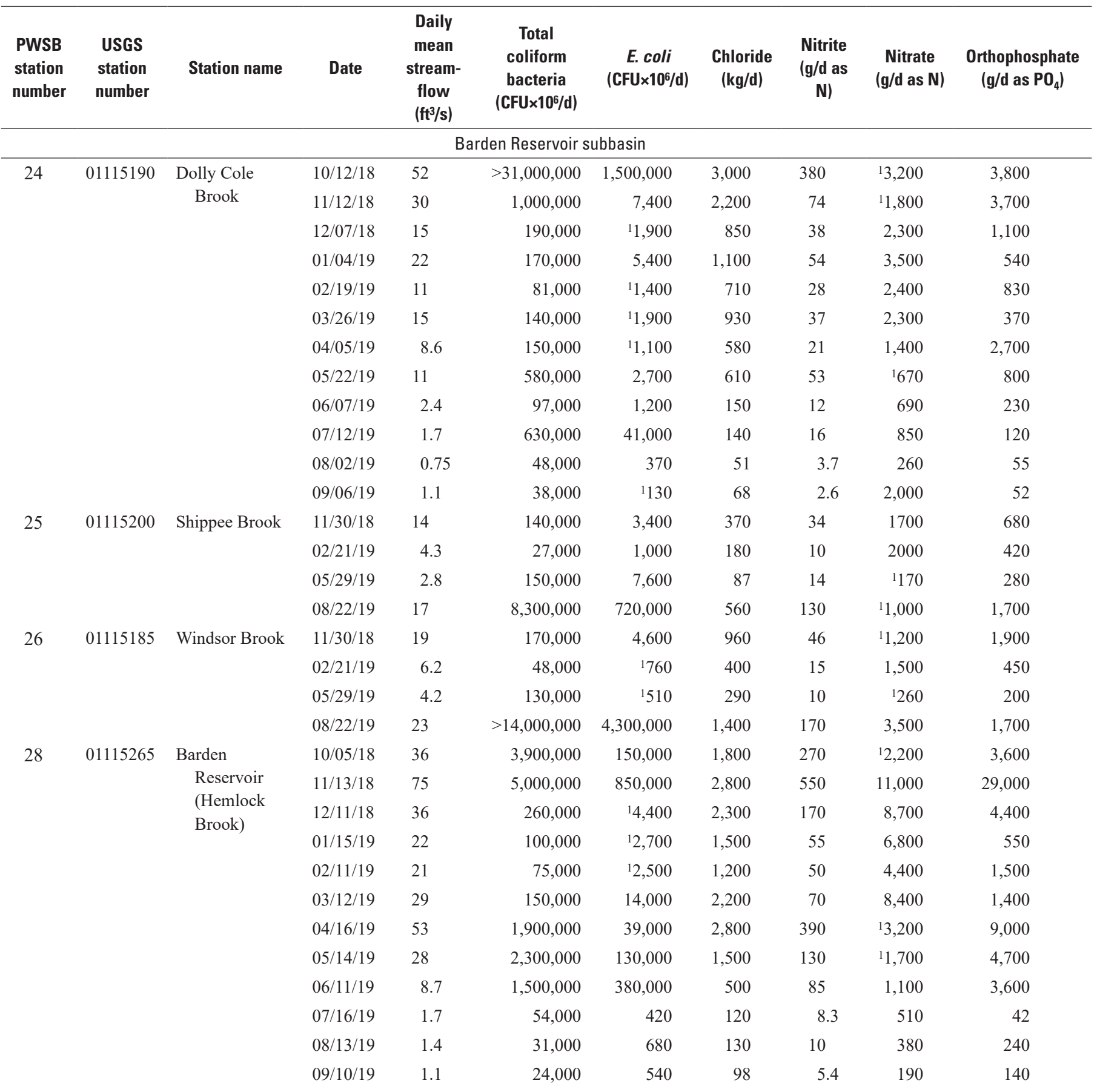


Table 4. Daily loads of bacteria, chloride, nitrite, nitrate, and orthophosphate in the Scituate Reservoir drainage area, Rhode Island, from 0ctober 1, 2018, through September 30, 2019.-Continued

[Water-quality data are from samples collected and analyzed by the Providence Water Supply Board (PWSB). Alternate station names are listed in parentheses for stations where different historical names were used for the same sampling location by the PWSB. Locations of stations shown on figure 1. USGS, U.S. Geological Survey; $\mathrm{ft}^{3} / \mathrm{s}$, cubic foot per second; CFU $\times 10^{6} / \mathrm{d}$; millions of colony forming units per day; E. coli, Escherichia coli; kg/d, kilogram per day; g/d, gram per day; $\mathrm{N}$, nitrogen; $\mathrm{PO}_{4}$, phosphate; <, less than; >, greater than]

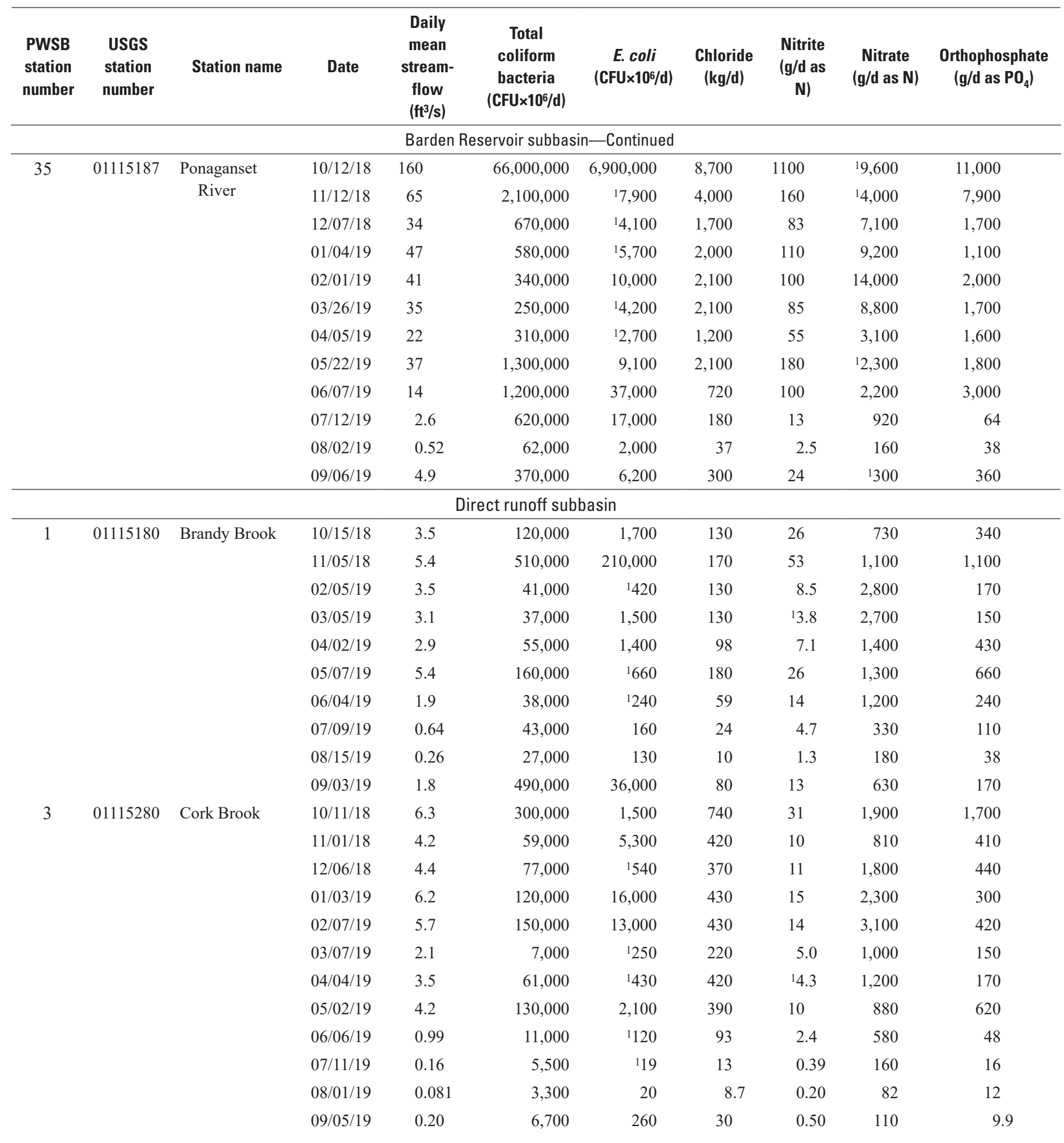


Table 4. Daily loads of bacteria, chloride, nitrite, nitrate, and orthophosphate in the Scituate Reservoir drainage area, Rhode Island, from 0ctober 1, 2018, through September 30, 2019.-Continued

[Water-quality data are from samples collected and analyzed by the Providence Water Supply Board (PWSB). Alternate station names are listed in parentheses for stations where different historical names were used for the same sampling location by the PWSB. Locations of stations shown on figure 1. USGS, U.S. Geological Survey; $\mathrm{ft}^{3} / \mathrm{s}$, cubic foot per second; CFU $\times 10^{6} / \mathrm{d}$; millions of colony forming units per day; E. coli, Escherichia coli; $\mathrm{kg} / \mathrm{d}$, kilogram per day; $\mathrm{g} / \mathrm{d}$, gram per day; $\mathrm{N}$, nitrogen; $\mathrm{PO}_{4}$, phosphate; $<$, less than; $>$, greater than]

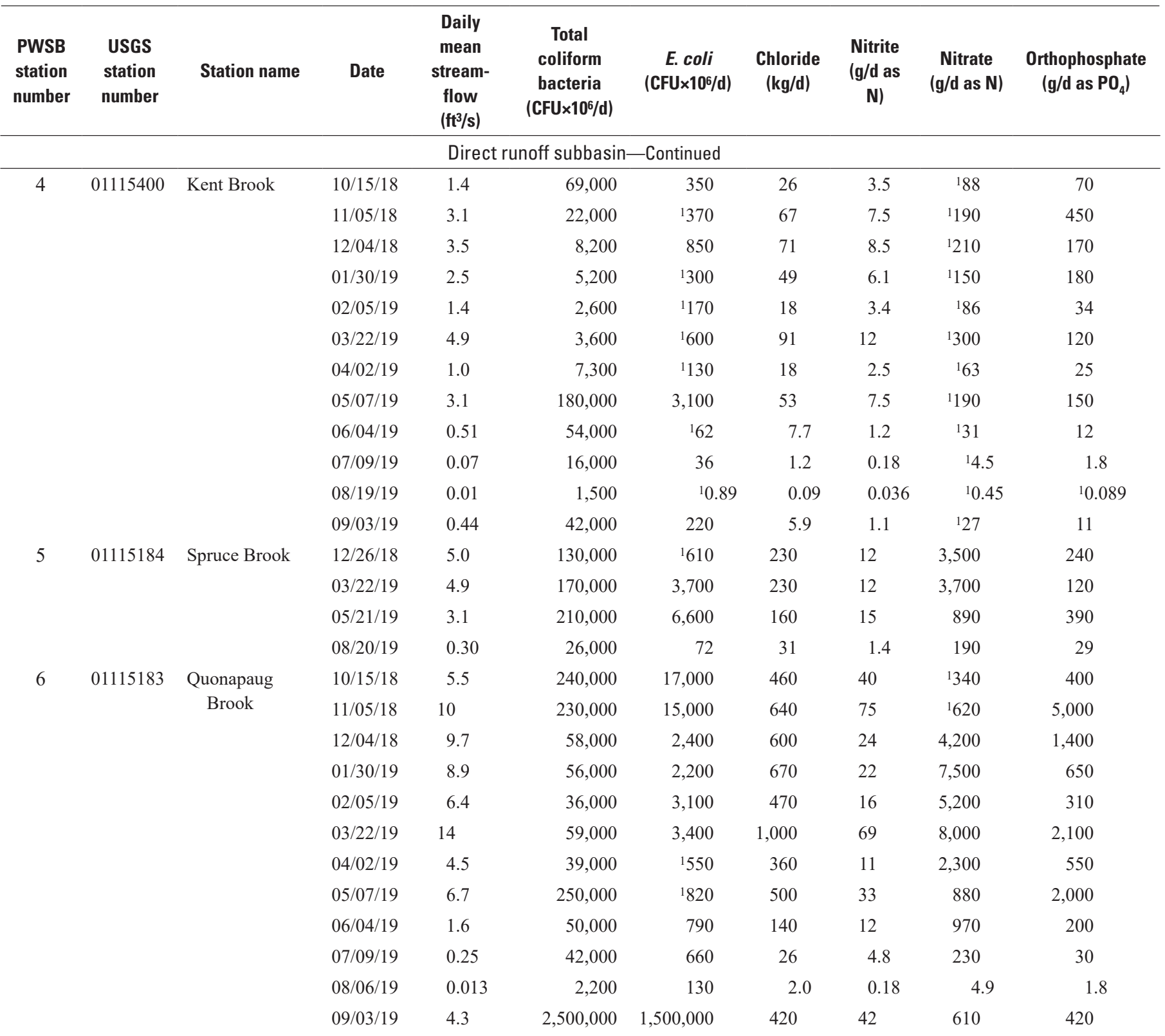


Table 4. Daily loads of bacteria, chloride, nitrite, nitrate, and orthophosphate in the Scituate Reservoir drainage area, Rhode Island, from 0ctober 1, 2018, through September 30, 2019.-Continued

[Water-quality data are from samples collected and analyzed by the Providence Water Supply Board (PWSB). Alternate station names are listed in parentheses for stations where different historical names were used for the same sampling location by the PWSB. Locations of stations shown on figure 1. USGS, U.S. Geological Survey; $\mathrm{ft}^{3} / \mathrm{s}$, cubic foot per second; CFU $\times 10^{6} / \mathrm{d}$; millions of colony forming units per day; E. coli, Escherichia coli; $\mathrm{kg} / \mathrm{d}$, kilogram per day; g/d, gram per day; $\mathrm{N}$, nitrogen; $\mathrm{PO}_{4}$, phosphate; <, less than; >, greater than]

\begin{tabular}{|c|c|c|c|c|c|c|c|c|c|c|}
\hline $\begin{array}{l}\text { PWSB } \\
\text { station } \\
\text { number }\end{array}$ & $\begin{array}{c}\text { USGS } \\
\text { station } \\
\text { number }\end{array}$ & Station name & Date & $\begin{array}{c}\text { Daily } \\
\text { mean } \\
\text { stream- } \\
\text { flow } \\
\left(\mathrm{ft}^{3} / \mathrm{s}\right)\end{array}$ & $\begin{array}{c}\text { Total } \\
\text { coliform } \\
\text { bacteria } \\
\text { (CFU×106/d) }\end{array}$ & $\begin{array}{c}\text { E. coli } \\
\left.\text { (CFU } \times 10^{6} / \mathrm{d}\right)\end{array}$ & $\begin{array}{l}\text { Chloride } \\
\text { (kg/d) }\end{array}$ & $\begin{array}{l}\text { Nitrite } \\
(\mathrm{g} / \mathrm{d} \text { as } \\
\mathrm{N})\end{array}$ & $\begin{array}{c}\text { Nitrate } \\
(\mathrm{g} / \mathrm{d} \text { as } N)\end{array}$ & $\begin{array}{l}\text { Orthophosphate } \\
\left.\text { (g/d as } \mathrm{PO}_{4}\right)\end{array}$ \\
\hline \multicolumn{11}{|c|}{ Direct runoff subbasin-Continued } \\
\hline \multirow[t]{8}{*}{7} & \multirow[t]{8}{*}{01115297} & \multirow{8}{*}{$\begin{array}{l}\text { Wilbur Hollow } \\
\text { Brook }\end{array}$} & $10 / 11 / 18$ & 8.8 & 930,000 & 24,000 & 240 & 64 & 1540 & 640 \\
\hline & & & $12 / 06 / 18$ & 14 & 97,000 & 7,000 & 470 & 35 & 4,100 & 1,000 \\
\hline & & & $01 / 03 / 19$ & 17 & 91,000 & 4,200 & 400 & 42 & 4,700 & 420 \\
\hline & & & $02 / 07 / 19$ & 17 & 94,000 & 4,100 & 440 & 41 & 8,700 & 810 \\
\hline & & & 03/07/19 & 8.4 & 17,000 & ${ }^{1} 1,000$ & 320 & 21 & 6,000 & 830 \\
\hline & & & $04 / 04 / 19$ & 12 & 280,000 & ${ }^{1} 1,500$ & 340 & 30 & 1,500 & 600 \\
\hline & & & $08 / 01 / 19$ & 0.15 & 17,000 & 390 & 3.7 & 1.1 & 19.0 & 11 \\
\hline & & & 09/05/19 & 1.4 & 130,000 & 6,800 & 37 & 10 & 187 & 69 \\
\hline \multirow[t]{7}{*}{8} & \multirow[t]{7}{*}{01115276} & \multirow{7}{*}{$\begin{array}{l}\text { Westconnaug } \\
\text { Brook }\end{array}$} & $10 / 05 / 18$ & 14 & 450,000 & 3,500 & 510 & 35 & 1880 & $1<180$ \\
\hline & & & $11 / 19 / 18$ & 25 & 62,000 & 6,200 & 850 & 62 & 3,200 & 2500 \\
\hline & & & $12 / 28 / 18$ & 20 & 20,000 & 12,400 & 590 & 49 & 3,300 & 970 \\
\hline & & & $01 / 28 / 19$ & 25 & 74,000 & 6,200 & 840 & 62 & ${ }^{1} 1,500$ & 1800 \\
\hline & & & $02 / 15 / 19$ & 14 & 3,300 & ${ }^{1} 1,700$ & 410 & 33 & 1830 & 660 \\
\hline & & & $03 / 15 / 19$ & 15 & ${ }^{1} 1,800$ & ${ }^{1} 1,800$ & 450 & 36 & 1910 & 730 \\
\hline & & & $04 / 19 / 19$ & 15 & 110,000 & ${ }^{1} 1,900$ & 500 & 38 & 1950 & 760 \\
\hline \multirow{3}{*}{9} & \multirow{3}{*}{01115275} & \multirow{3}{*}{ Bear Tree Brook } & $03 / 22 / 19$ & 3.6 & 71,000 & 1440 & 350 & 17 & 3,700 & 1,000 \\
\hline & & & $05 / 21 / 19$ & 2.6 & 390,000 & 4,000 & 320 & 13 & 2,200 & 190 \\
\hline & & & 08/20/19 & 0.46 & 43,000 & 950 & 78 & 2.2 & 910 & 45 \\
\hline \multirow[t]{3}{*}{32} & \multirow[t]{3}{*}{01115178} & \multirow{3}{*}{$\begin{array}{l}\text { Unnamed } \\
\text { tributary } 1 \\
\text { to Scituate } \\
\text { Reservoir } \\
\text { (Pine Swamp } \\
\text { Brook) }\end{array}$} & $10 / 25 / 18$ & 0.55 & 13,000 & ${ }^{1} 68$ & 25 & 2.7 & 320 & 140 \\
\hline & & & 03/11/19 & 1.1 & 17,000 & ${ }^{1} 140$ & 37 & 2.7 & 1,300 & 55 \\
\hline & & & $06 / 28 / 19$ & 0.24 & 30,000 & 1,400 & 6.4 & 3.5 & 150 & 41 \\
\hline
\end{tabular}


Table 4. Daily loads of bacteria, chloride, nitrite, nitrate, and orthophosphate in the Scituate Reservoir drainage area, Rhode Island, from 0ctober 1, 2018, through September 30, 2019.-Continued

[Water-quality data are from samples collected and analyzed by the Providence Water Supply Board (PWSB). Alternate station names are listed in parentheses for stations where different historical names were used for the same sampling location by the PWSB. Locations of stations shown on figure 1. USGS, U.S. Geological Survey; $\mathrm{ft}^{3} / \mathrm{s}$, cubic foot per second; CFU $\times 10^{6} / \mathrm{d}$; millions of colony forming units per day; E. coli, Escherichia coli; $\mathrm{kg} / \mathrm{d}$, kilogram per day; g/d, gram per day; $\mathrm{N}$, nitrogen; $\mathrm{PO}_{4}$, phosphate; $<$, less than; $>$, greater than]

\begin{tabular}{|c|c|c|c|c|c|c|c|c|c|c|}
\hline $\begin{array}{l}\text { PWSB } \\
\text { station } \\
\text { number }\end{array}$ & $\begin{array}{c}\text { USGS } \\
\text { station } \\
\text { number }\end{array}$ & Station name & Date & $\begin{array}{c}\text { Daily } \\
\text { mean } \\
\text { stream- } \\
\text { flow } \\
\left(\mathrm{ft}^{3} / \mathrm{s}\right)\end{array}$ & $\begin{array}{c}\text { Total } \\
\text { coliform } \\
\text { bacteria } \\
\text { (CFU×106/d) }\end{array}$ & $\begin{array}{c}\text { E. coli } \\
\left.\text { (CFU } \times 10^{6} / \mathrm{d}\right)\end{array}$ & $\begin{array}{c}\text { Chloride } \\
\text { (kg/d) }\end{array}$ & $\begin{array}{c}\text { Nitrite } \\
\text { (g/d as } \\
\text { N) }\end{array}$ & $\begin{array}{c}\text { Nitrate } \\
(\mathbf{g} / \mathbf{d} \text { as } N)\end{array}$ & $\begin{array}{c}\text { Orthophosphate } \\
\left(\mathrm{g} / \mathrm{d} \text { as } \mathrm{PO}_{4}\right)\end{array}$ \\
\hline \multicolumn{11}{|c|}{ Direct runoff subbasin-Continued } \\
\hline \multirow[t]{3}{*}{33} & \multirow[t]{3}{*}{01115182} & \multirow{3}{*}{$\begin{array}{l}\text { Unnamed } \\
\text { tributary } 3 \\
\text { to Scituate } \\
\text { Reservoir } \\
\text { (Halls Estate } \\
\text { Brook) }\end{array}$} & $11 / 26 / 18$ & 1.3 & 15,000 & 660 & 37 & ${ }^{1} 1.6$ & 640 & 130 \\
\hline & & & $04 / 24 / 19$ & 1.4 & 35,000 & ${ }^{1} 170$ & 45 & 3.5 & 410 & 210 \\
\hline & & & $09 / 25 / 19$ & 0.0040 & 400 & 2.1 & 0.72 & 0.032 & 1.9 & 0.53 \\
\hline \multicolumn{11}{|c|}{ Moswansicut Reservoir subbasin } \\
\hline \multirow[t]{9}{*}{19} & \multirow[t]{9}{*}{01115170} & \multirow{9}{*}{$\begin{array}{l}\text { Moswansicut } \\
\text { Reservoir } \\
\text { (Moswansicut } \\
\text { Stream north, } \\
\text { Moswansicut } \\
\text { Pond) }\end{array}$} & $10 / 18 / 18$ & 4.6 & 49,000 & ${ }^{1} 560$ & 740 & 11 & 1280 & 110 \\
\hline & & & $02 / 14 / 19$ & 11 & 2,800 & ${ }^{1} 1,400$ & 1,600 & 28 & 6,400 & 280 \\
\hline & & & $03 / 14 / 19$ & 8.4 & ${ }^{1} 1,000$ & ${ }^{1} 1,000$ & 1,300 & 21 & 5,600 & 210 \\
\hline & & & $04 / 11 / 19$ & 10 & ${ }^{1} 1,200$ & ${ }^{1} 1,200$ & 1,500 & 25 & 6,400 & 500 \\
\hline & & & $05 / 16 / 19$ & 10 & 12,000 & ${ }^{1} 1,200$ & 1,600 & 48 & 4,600 & 240 \\
\hline & & & $06 / 13 / 19$ & 9.6 & 150,000 & ${ }^{1} 1,200$ & 1,300 & 47 & ${ }^{1} 590$ & 470 \\
\hline & & & $07 / 25 / 19$ & 3.1 & 220,000 & 1380 & 410 & 7.6 & ${ }^{1} 190$ & 76 \\
\hline & & & 08/08/19 & 1.1 & 110,000 & ${ }^{1} 140$ & 160 & 2.7 & ${ }^{1} 68$ & 55 \\
\hline & & & $09 / 12 / 19$ & 0.71 & 140,000 & 170.0 & 100 & 1.7 & 143 & 17 \\
\hline 21 & 01115165 & $\begin{array}{l}\text { Unnamed } \\
\text { tributary } 2 \text { to } \\
\text { Moswansicut } \\
\text { Reservoir } \\
\text { (Brook from } \\
\text { Kimball } \\
\text { Reservoir) }\end{array}$ & $03 / 28 / 19$ & 0.84 & 19,000 & ${ }^{1} 100$ & 92 & 4.1 & 1,000 & 41 \\
\hline \multirow[t]{12}{*}{14} & \multirow[t]{12}{*}{01115110} & \multirow{12}{*}{$\begin{array}{l}\text { Huntinghouse } \\
\text { Brook }\end{array}$} & $10 / 19 / 18$ & 6.2 & 170,000 & 13,000 & 290 & 15 & 1380 & 600 \\
\hline & & & $11 / 09 / 18$ & 22 & 340,000 & 11,000 & 780 & 54 & ${ }^{1} 1,300$ & 2,200 \\
\hline & & & $12 / 18 / 18$ & 21 & 450,000 & 26,000 & 730 & 51 & 4,700 & 1,000 \\
\hline & & & $01 / 11 / 19$ & 16 & 320,000 & 12,000 & 490 & 39 & 4,800 & 1,200 \\
\hline & & & $02 / 08 / 19$ & 26 & 200,000 & 19,000 & 840 & 63 & 8,400 & 1,300 \\
\hline & & & 03/08/19 & 7.0 & 23,000 & 1860 & 320 & 17 & 3,100 & 340 \\
\hline & & & $04 / 18 / 19$ & 15 & 320,000 & 7,300 & 590 & 37 & 1,900 & 730 \\
\hline & & & $05 / 10 / 19$ & 10 & 190,000 & 4,900 & 370 & 25 & ${ }^{1} 610$ & 740 \\
\hline & & & $06 / 20 / 19$ & 5.6 & $2,700,000$ & 290,000 & 230 & 55 & 2,200 & 960 \\
\hline & & & $07 / 31 / 19$ & 0.28 & 25,000 & 870 & 9.8 & 1.3 & 96 & 20 \\
\hline & & & 08/09/19 & 2.7 & $1,600,000$ & 57,000 & 99 & 13 & 730 & 260 \\
\hline & & & $09 / 17 / 19$ & 0.65 & 26,000 & 160 & 30 & 1.6 & 180 & 64 \\
\hline
\end{tabular}


Table 4. Daily loads of bacteria, chloride, nitrite, nitrate, and orthophosphate in the Scituate Reservoir drainage area, Rhode Island, from 0ctober 1, 2018, through September 30, 2019.-Continued

[Water-quality data are from samples collected and analyzed by the Providence Water Supply Board (PWSB). Alternate station names are listed in parentheses for stations where different historical names were used for the same sampling location by the PWSB. Locations of stations shown on figure 1. USGS, U.S. Geological Survey; $\mathrm{ft}^{3} / \mathrm{s}$, cubic foot per second; CFU $\times 10^{6} / \mathrm{d}$; millions of colony forming units per day; E. coli, Escherichia coli; kg/d, kilogram per day; g/d, gram per day; $\mathrm{N}$, nitrogen; $\mathrm{PO}_{4}$, phosphate; <, less than; >, greater than]

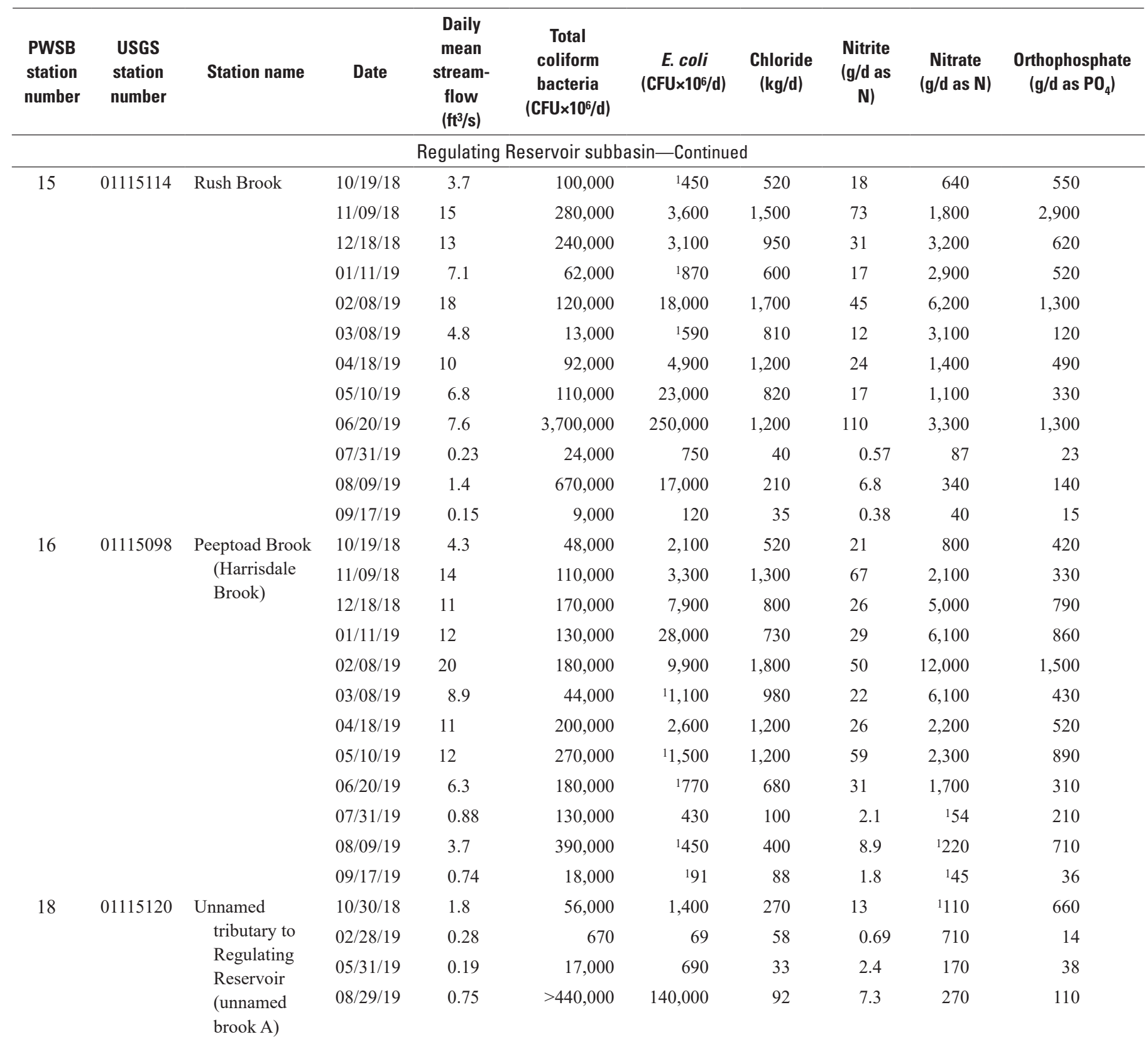


Table 4. Daily loads of bacteria, chloride, nitrite, nitrate, and orthophosphate in the Scituate Reservoir drainage area, Rhode Island, from 0ctober 1, 2018, through September 30, 2019.-Continued

[Water-quality data are from samples collected and analyzed by the Providence Water Supply Board (PWSB). Alternate station names are listed in parentheses for stations where different historical names were used for the same sampling location by the PWSB. Locations of stations shown on figure 1. USGS, U.S. Geological Survey; $\mathrm{ft}^{3} / \mathrm{s}$, cubic foot per second; CFU $\times 10^{6} / \mathrm{d}$; millions of colony forming units per day; E. coli, Escherichia coli; $\mathrm{kg} / \mathrm{d}$, kilogram per day; g/d, gram per day; $\mathrm{N}$, nitrogen; $\mathrm{PO}_{4}$, phosphate; $<$, less than; $>$, greater than]

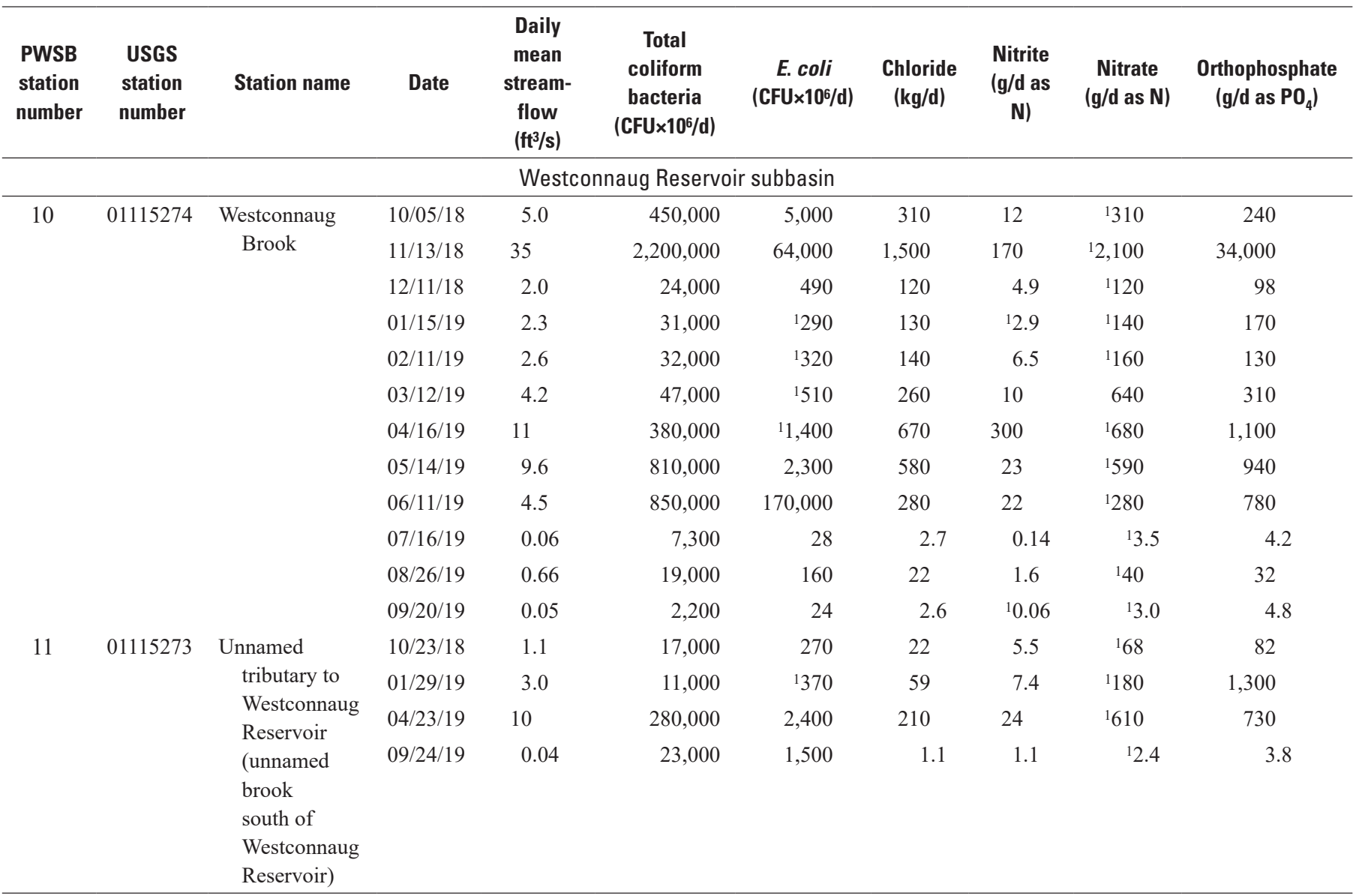

${ }^{1}$ Values were censored and are reported as one-half the method detection limit. 

For more information about this report, contact:

Director, New England Water Science Center

U.S. Geological Survey

10 Bearfoot Road

Northborough, MA 01532

dc_nweng@usgs.gov

or visit our website at

https://www.usgs.gov/centers/new-england-water

Publishing support provided by the Pembroke and Lafayette Publishing Service Centers 


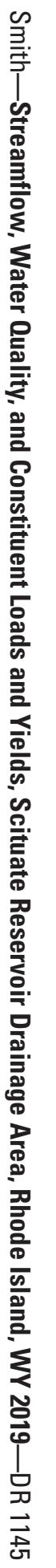

